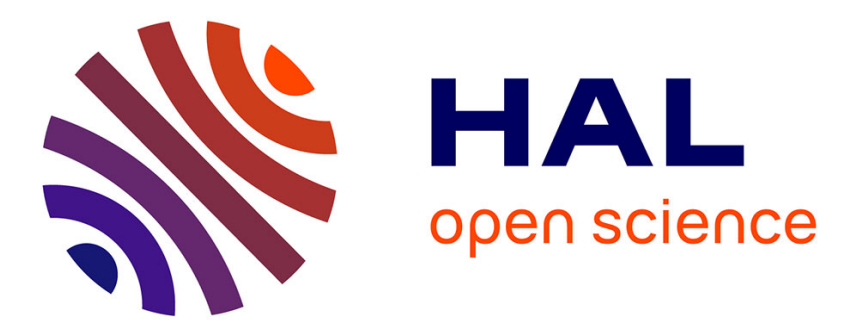

\title{
Groundwater Control and Process Variability on the Equatorial Layered Deposits of Kotido Crater, Mars
}

M. Pondrelli, A. Rossi, L. Le Deit, G. Schmidt, R. Pozzobon, E. Hauber, F. Salese

\section{- To cite this version:}

M. Pondrelli, A. Rossi, L. Le Deit, G. Schmidt, R. Pozzobon, et al.. Groundwater Control and Process Variability on the Equatorial Layered Deposits of Kotido Crater, Mars. Journal of Geophysical Research. Planets, 2019, 124 (3), pp.779-800. 10.1029/2018JE005656 . hal-02552360

\author{
HAL Id: hal-02552360 \\ https://hal.science/hal-02552360
}

Submitted on 31 Dec 2021

HAL is a multi-disciplinary open access archive for the deposit and dissemination of scientific research documents, whether they are published or not. The documents may come from teaching and research institutions in France or abroad, or from public or private research centers.
L'archive ouverte pluridisciplinaire HAL, est destinée au dépôt et à la diffusion de documents scientifiques de niveau recherche, publiés ou non, émanant des établissements d'enseignement et de recherche français ou étrangers, des laboratoires publics ou privés.

$$
\text { Copyright }
$$




\section{RESEARCH ARTICLE 10.1029/2018JE005656 \\ Special Section: \\ Planetary Mapping: Methods, Tools for Scientific Analysis and Exploration \\ Key Points: \\ - We mapped the Equatorial Layered Deposits of Kotido crater, recognizing their geological variability and stratigraphic relations \\ - Fluid expulsion processes controlled by groundwater fluctuations appear to be the driving mechanism on the deposition/preservation \\ - The importance of groundwater control raises issues on the possible lateral relations with other deposits/morphologies in Arabia Terra}

Supporting Information:

- Supporting Information S1

- Table S1

Correspondence to:

M. Pondrelli,

monica.pondrelli@unich.it

Citation:

Pondrelli, M., Rossi, A. P., Le Deit, L., Schmidt, G., Pozzobon, R., Hauber, E., \& Salese, F. (2019). Groundwater control and process variability on the Equatorial Layered Deposits of Kotido crater, Mars. Journal of Geophysical Research: Planets, 124, 779-800. https:// doi.org/10.1029/2018JE005656

Received 24 APR 2018 Accepted 24 JAN 2019

Accepted article online 1 FEB 2019

Published online 18 MAR 2019

Author Contributions:

Conceptualization: M. Pondrelli, A. P. Rossi, L. Le Deit, R. Pozzobon, E. Hauber, F. Salese

Data curation: A. P. Rossi, L. Le Deit, G. Schmidt, R. Pozzobon

Formal analysis: M. Pondrelli, L. Le Deit, G. Schmidt, F. Salese

Investigation: M. Pondrelli, L. Le Deit (continued)

(C)2019. American Geophysical Union. All Rights Reserved.

\section{Groundwater Control and Process Variability on the Equatorial Layered Deposits of Kotido Crater, Mars}

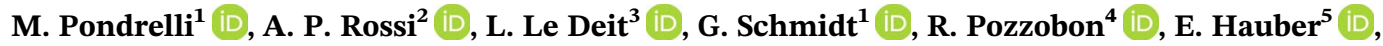 \\ and F. Salese ${ }^{1,3,6}$ iD
}

${ }^{1}$ International Research School of Planetary Sciences, Università d'Annunzio, Pescara, Italy, ${ }^{2}$ Jacobs University Bremen, Bremen, Germany, ${ }^{3}$ Laboratoire de Planétologie et Géodynamique, LPG-Nantes, CNRS UMR 6112, Université de Nantes, Nantes, France, ${ }^{4}$ Dipartimento di Geoscienze, Università degli Studi di Padova, Padua, Italy, ${ }^{5}$ German Aerospace Center (DLR), Institut für Planetenforschung, Berlin-Adlershof, Germany, ${ }^{6}$ Faculty of Geosciences, Utrecht University, Utrecht, The Netherlands

Abstract Understanding the origin of the Hesperian-aged sulfate-bearing Equatorial Layered Deposits (ELDs) is crucial to infer Mars' climatic conditions during their formation and to assess their habitability potential. We investigated well-exposed ELDs in Kotido crater (Arabia Terra) and produced a detailed geological map of the crater infill, distinguishing different units within the ELDs based upon their morphological and sedimentological characteristics.

The ELDs consist of interbedded light-toned, darker-toned deposits and mounds, associated with possible fissure ridges. Although heavily eroded by younger eolian processes, we interpret these deposits and their associated morphologies as remnants of depositional features and propose that they are the result of fluid, gas, and sediment expulsion processes sourced from the groundwater. The textural characteristics, their depositional geometry, the associated morphologies, and the inferred composition of the light-toned deposits suggest an evaporitic origin, whereas the darker-toned deposits might reflect clastic sedimentary processes, related or not to fluid expulsion and/or residual deposition following dissolution of the evaporites. The relative ratio of fluids, salts, and clasts controlled the depositional process, analogous to what happens in terrestrial playas. The controls on fluid expulsion is interpreted to depend on groundwater emplacement and fluctuations, possibly related to climatic changes, and to the interactions with the fractures related to the crater formation, which allowed the actual upwelling from a pressurized aquifer.

Plain Language Summary Light-toned layered deposits rich in sulfates are widespread on Mars in several locations. Understanding how these deposits formed is crucial to infer the climatic conditions during Martian history and, in light of the fact that potentially similar deposits on Earth have been shown to be conducive to bacterial life, is critical in the search for habitable environments on Mars. We focused on Kotido crater because it shows a remarkable infill and excellent data coverage. We drew a detailed geological map, recognizing subunits interbedded within the layered deposits: light-toned and darker-toned layers, subconical mounds, and associated fractures. We interpret these materials to result from episodes of water upwelling sourced from the subsurface: a mixture of fluids, gases, and sediments emerged in Kotido leading to the deposition of the different subunits depending on the relative ratio of the upwelling materials in the different phases. The mounds and fractures would represent the morphological expression of the upwelling process, while the light- and darker-toned material would represent the resulting deposits. The proposed mechanism is identical to that of terrestrial environments such as playa and spring deposition typical of arid settings where bacterial life is well adapted.

\section{Introduction}

Many sites in the equatorial regions of Mars (roughly within $30^{\circ}$ north and south) host light-toned layered deposits, including Valles Marineris and the chaotic terrains (Al-Samir et al., 2017; Baioni \& Tramontana, 2017; Chapman \& Tanaka, 2001; Davis et al., 2018; Flahaut, Quantin, Allemand, Thomas, \& Le Deit, 2010; Flahaut, Quantin, Allemand, Thomas, 2010; Fueten et al., 2008, 2014, 2017; Glotch \& Rogers, 2007; Le Deit et al., 2008; Lucchitta et al., 1992; Murchie et al., 2009; Noel et al., 2015; Quantin et al., 2005; Schmidt et al., 2018; Weitz et al., 2012, 2008), interior crater deposits (Allen \& Oehler, 2008; Kite et al., 
Methodology: M. Pondrelli, A. P. Rossi, L. Le Deit, G. Schmidt, R. Pozzobon, F. Salese

Validation: M. Pondrelli, E. Hauber Writing - original draft: M. Pondrelli, L. Le Deit Writing - review \& editing: A. P. Rossi, L. Le Deit, G. Schmidt, R. Pozzobon, E. Hauber, F. Salese
2013; Le Deit et al., 2013; Lewis et al., 2008; Murana, 2018; Pondrelli et al., 2015, 2011; Zabrusky et al., 2012), the northern rim of Hellas basin (Ansan et al., 2011; Day et al., 2016; Moore \& Wilhelms, 2007; Salese et al., 2016; Wilson et al., 2007), and the intercrater plains of Arabia Terra and Meridiani Planum (Grotzinger et al., 2005; Malin \& Edgett, 2000; McLennan et al., 2005; Pondrelli et al., 2015). Dismissing the fluvio-deltaic deposits, they are grouped under the informal name of Equatorial Layered Deposits (ELDs; Hynek et al., 2002; Okubo et al., 2009) and are included in the Hesperian and Noachian highland undivided unit of the most recent global geological map (Tanaka et al., 2014). The spectral data obtained from Observatoire pour la Minéralogie, l'Eau, les Glaces, et l'Activité (e.g., Bibring et al., 2005) on board the ESA Mars Express mission and from the Compact Reconnaissance Imaging Spectrometer for Mars (CRISM) on board the NASA Mars Reconnaissance Orbiter (MRO; Murchie et al., 2007) detected monohydrated and/or polyhydrated sulfates in association with most of the ELDs (e.g., Bibring et al., 2006; Gendrin et al., 2005; Mangold et al., 2008).

According to studies from different locations (e.g., Bibring et al., 2006; Gendrin et al., 2005; Le Deit et al., 2008; Pondrelli et al., 2015; Poulet et al., 2008), the stratigraphic distribution of ELDs ranges from the Noachian-Hesperian transition up to the lower Hesperian. These deposits would postdate the clay-bearing deposits of Noachian age, thus marking a major environmental change in Mars history from alkaline to acidic environments (Bibring et al., 2006).

ELDs depositional environment(s) cover a wide range of possibilities, probably because of the large variety of geographic locations and geological contexts in which they are found. Proposed depositional environments include lacustrine (Fueten et al., 2017; Lucchitta et al., 1992; Newsom et al., 2003), sub-ice volcanic (Chapman \& Tanaka, 2002; Komatsu et al., 2004), weathering of basalts (Madden et al., 2004), pyroclastic (Hynek et al., 2002; Kerber et al., 2012; Scott \& Tanaka, 1982), impact base surge (Knauth et al., 2005), dust air fall (Michalski \& Niles, 2012; Tanaka, 2000), eolian (Bennett \& Bell, 2016), interplay between air fall and eolian processes and groundwater fluctuations (Andrews-Hanna et al., 2007, 2010; Andrews-Hanna \& Lewis, 2011; Grotzinger et al., 2005; Murchie et al., 2009; Zabrusky et al., 2012), and groundwater upwelling leading to spring deposit precipitation or mud volcano deposition (Rossi et al., 2008; Allen \& Oehler, 2008; Oehler \& Allen, 2010; Pondrelli et al., 2015, 2011; Franchi et al., 2014).

Arabia Terra represents a strategic location in order to better characterize the ELDs and their potential global geological significance because (a) here the transition between highlands and lowlands occurs without a sharp dichotomy but through a gently north dipping landscape that may make it easier to understand the possible interactions with groundwater (Figure 1a), (b) many authors reported evidence suggesting a control by groundwater (e.g., Andrews-Hanna et al., 2007, 2010; Andrews-Hanna \& Lewis, 2011; Franchi et al., 2014; Oehler \& Allen, 2010; Pondrelli et al., 2015; Rossi et al., 2008; Zabrusky et al., 2012), and (c) ELDs in Arabia Terra show a considerable geological variability in terms of geometries of the deposits/basins, morphological associations, sedimentary structures, and mineralogy (e.g., Allen \& Oehler, 2008; Franchi et al., 2014; Oehler \& Allen, 2010; Pondrelli et al., 2015, 2011; Zabrusky et al., 2012). Moreover, the area is close to and genetically connected with Meridiani Planum (Grotzinger et al., 2005), where the measurements acquired through the Mars Exploration Rover (MER) Opportunity provide a unique ground truth control, and also close to the ExoMars 2020 landing site in Oxia Planum.

The geological variability of these deposits imposes the necessity of detailed analyses in order to distinguish and map the different types of layered deposits and the understanding of their mutual vertical and lateral stratigraphic relations. Furthermore, the identification of the ELDs depositional geometries and architectures is crucial to constrain the role of erosion, ultimately infer the depositional processes, and define a landscape of laterally and vertically related depositional environments.

The Kotido crater (centered $9.1^{\circ} \mathrm{W}, 1^{\circ} \mathrm{N}$; Figures $1 \mathrm{a}, 1 \mathrm{~b}$, and $2 \mathrm{a}$ ) is one of the many crater basins in Arabia Terra (including among others Becquerel, Firsoff, Crommelin, Vernal, and Danielson craters) where ELDs have been found. It represents a promising target because it shows a very distinct set of ELDs with limited dust cover and it is relatively small so it can be mapped in detail using full coverage from both the High Resolution Stereo Camera (HRSC) on board Mars Express (Jaumann et al., 2015; Neukum et al., 2004) and Context Camera (CTX) on board MRO (Malin et al., 2007). Stereo pairs from the High-Resolution Imaging Science Experiment (HiRISE) on board MRO (McEwen et al., 2007) exist, including one that extend N-S across nearly the entire crater, providing constraints on the layer geometries throughout the basin (Figure 1b). 


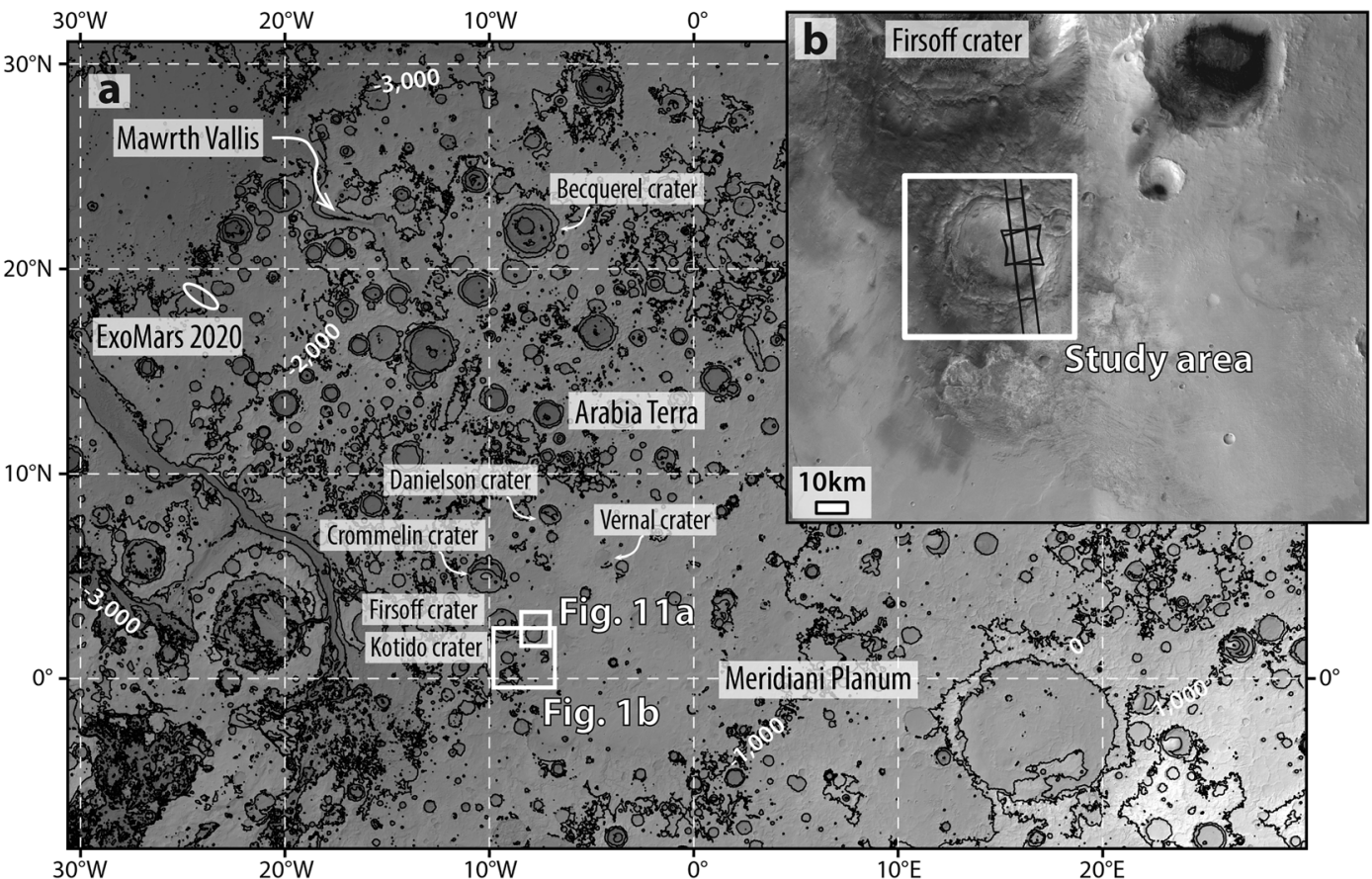

Figure 1. The Kotido crater in the context of Arabia Terra. (a) Mars Orbiter Laser Altimete-based shaded relief map showing Arabia Terra. Topographic contours (in black, 1,000-m spacing) are indicated. The white inset represents the location of 1b. (b) Location map of Kotido crater on HRSC mosaic. The mapped area is outlined. The area is fully CTX covered, while the footprints of HiRISE images and CRISM scenes (hourglass shape) are shown. The HiRISE images represent a stereo pair from which a DEM has been extracted.

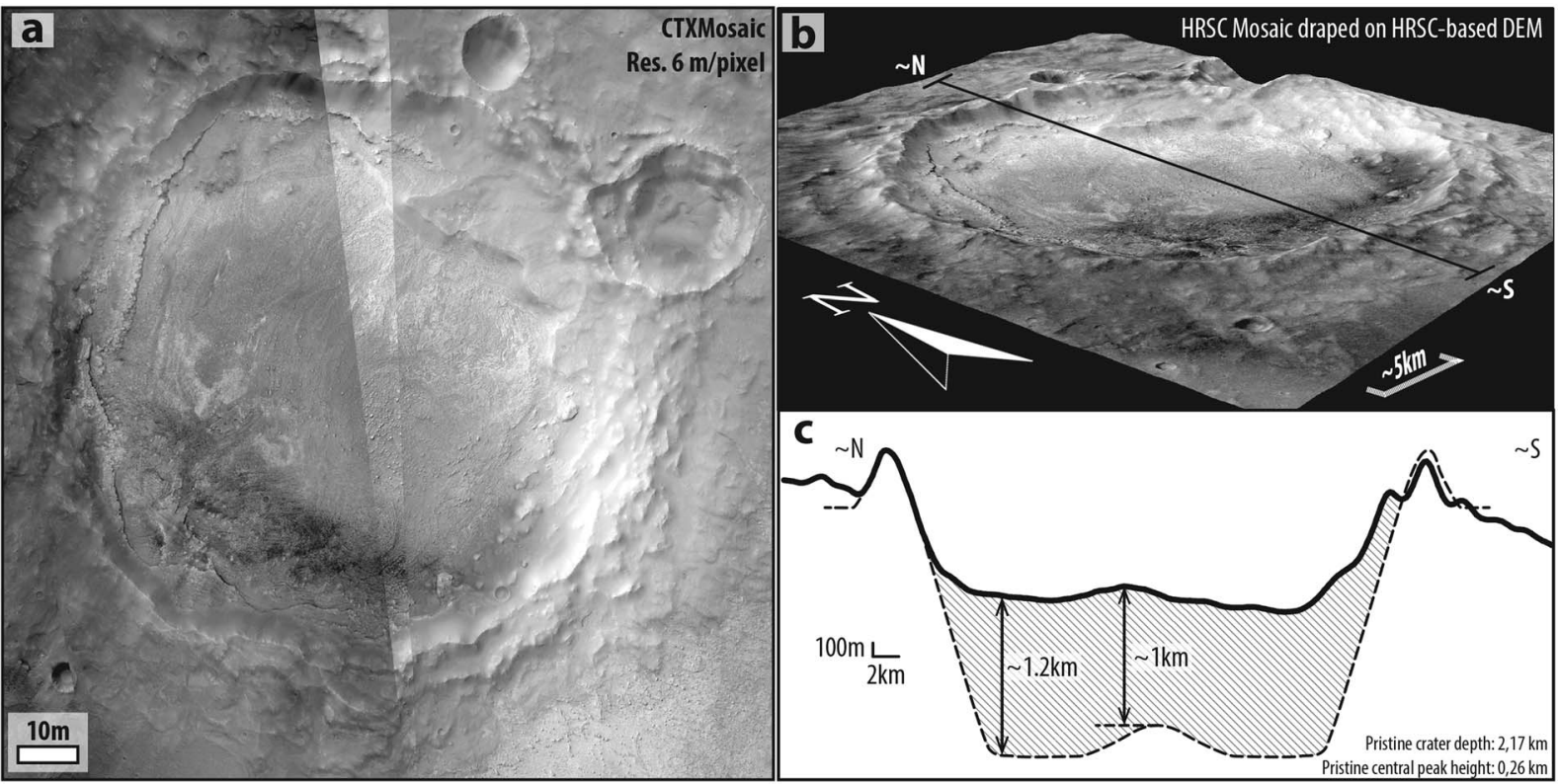

Figure 2. (a) CTX mosaic of Kotido crater. The mosaic is obtained from the images P17_007770_1794_XN_00S008W (Res. 5.46 m/pixel), B19_016921_1818_XN_01N009W (Res. 5.54 m/pixel), and P06_003221_1815_XN_01N009W (Res. 5.38 m/pixel). (b) Perspective view of Kotido crater (HRSC mosaic draped on HRSC DEM) showing the trace of the topographic profile shown in c (vertical exaggeration: 2). (c) The thicker line corresponds to the present profile (based on HRSC DEM) while the thinner dashed line to the inferred profile immediately following the impact (Garvin et al., 2003). The hatched area represents, although roughly, the basin infill. 
We interpreted the basin-wide and internal architecture of the ELDs and analyzed their morphologies, textures, sedimentary structures, and composition characteristics with the aim to understand the processes and environments of their formation. We then discuss our results to infer the geological setting and evolution of Kotido crater in the framework of Arabia Terra clay- and sulfate-bearing deposition (Salese et al., 2019).

\section{Materials and Methods}

HRSC data were processed using the JPL/DLR (Jet Propulsion Laboratory/Deutsches Zentrum für Luft-und Raumfahrt) Video Image Communication and Retrieval environment software. The Integrated Software for Imagers and Spectrometers made by the U.S. Geological Survey (Anderson et al., 2004) was used for CTX and HiRISE data. The resulting georeferenced images were imported into in a GIS-based platform (ESRI ArcGIS) in order to allow the integration of observations at different scales.

Digital elevation models (DEMs) were produced from CTX and HiRISE stereo pairs with the NASA Ames Stereo Pipeline suite (Broxton \& Edwards, 2008; Moratto et al., 2010). CTX and HiRISE data sets were adjusted to the areoid, and the resulting DEMs were tied to the regional HRSC mosaic (in turn tied and bundle adjusted to Mars Orbiter Laser Altimeter; Smith et al., 2001). Three-dimensional visualization and subsequent observations/measurements were performed through the analysis software QPS Fledermaus, Orion (Pangaea Scientific, 2006-2011), and ESRI ArcScene. Layer thicknesses were obtained by measuring elevation and distance between each visible layer within a HiRISE DEM. Three transects were made along a line parallel to slope and produced 13 layer thickness measurements. Measurements were corrected for dip and typically have an error of $\pm 0.3 \mathrm{~m}$. Layer attitudes were measured within a HiRISE stereo pair and obtained using Orion. The range of error within the dip measurements was between $\pm 1^{\circ}$ and $\pm 9^{\circ}$. The error is always less than the value of the dip to guarantee that the dip directions are valid (e.g., Fueten et al.,2008, 2014, 2017; Schmidt, Fueten, et al., 2018).

Hyperspectral data acquired by MRO's instrument CRISM were processed using the CAT (CRISM Analysis Toolkit; Morgan et al., 2014) extension, developed by the CRISM Science Team, in ENVI software (Exelis VIS). The spectral parameter maps were computed using the revised spectral parameter summary products (Viviano-Beck et al., 2014).

The topography of the crater (depth, rim height, central peak height, and diameter) following the impact has been derived using the equations provided by Garvin et al. (2003) and Robbins and Hynek (2013). This reconstruction is simply intended to provide the order of magnitude of the basin infill and not exact values.

The geological map was made using the software ESRI ArcGIS, at CTX scale (i.e., 1:20,000), by integrating geological (layered/nonlayered deposits, tone, texture, and nature of the stratigraphic contacts), geomorphological (geometry of the deposits from basin to HiRISE scale, erosional patterns), available hints on mineralogy, and the stratigraphic positions within the succession. With the aim of mapping the units not just as landforms (i.e., geomorphological map), but as deposits associated to landforms with unique layer attitudes and what it can be inferred of its composition on the base of the available data (i.e., geological map; Pondrelli et al., 2018).

\section{Geology of Kotido Crater}

Kotido crater is a complex crater that is $\sim 40 \mathrm{~km}$ in diameter and about 1-km deep, to the top surface of the infill (Figures 2a and 2b). Its inferred geometry after the impact, computed using the methods described in Garvin et al. (2003) and Robbins and Hynek (2013), is represented in Figure 2c together with the present topography as measured in the HRSC-based DEM. Even considering the intrinsic limits of this methodology (i.e., impossibility to quantify the amount of eroded or eventually deposited other materials), and the degree of arbitrariness in the process of superposition of the two profiles, which precludes obtaining precise values, the order of magnitude of the basin infill thickness can be roughly estimated to be about $1 \mathrm{~km}$. The thickness of the infill is more or less constant throughout the crater, with a slightly higher thickness in the areas approaching the crater margins (Figure 2c), where the ELDs consist of flat-bedded or gently folded layers that are unlikely to have resulted from landslides or slump processes. In that respect, Kotido is different from the nearby Firsoff crater, where the maximum thickness of the basin infill corresponds to the crater central peak (Pondrelli et al., 2015). 
The geologic map constrains the stratigraphic framework of the basin, but also the heterogeneity within the ELDs deposits (Figure 3). The overall succession was divided into informal units with the exception of a few units introduced by Tanaka et al. (2014). The units that we introduced have not been formally defined because their lateral/vertical relations with similar deposits in other basins or with the clay-bearing deposits located in other parts of Arabia Terra are still largely unknown. The present work focuses on the units which form the ELDs, and we refer to Pondrelli et al. (2015) for a detailed description of the other units, as well as their mutual stratigraphic relations.

\subsection{Units Predating ELDs}

The substratum on which the ELDs are deposited is thought to be made of the Middle Noachian highland unit ( $\mathrm{mNh}$ ), which is almost exclusively found at the crater rim. It consists of massive medium-toned material with sharp ridges suggestive of a competent lithology. This unit corresponds to the subdued cratered unit $\left(\mathrm{Nhc}_{2}\right)$ and moderately eroded crater unit $\left(\mathrm{c}_{2}\right)$ mapped by Hynek and Di Achille (2017). The $\mathrm{c}_{2}$ unit (Hynek \& Di Achille, 2017) corresponds to the Kotido crater rim. According to Tanaka et al. (2014), and Hynek and Di Achille (2017), it represents an undifferentiated mixture of impact, volcanic, fluvial, and basin materials.

In the northeastern part of the study area $\mathrm{mNh}$ is covered by the ejecta from a roughly 10-km large crater that impacted the Kotido crater rim. We tentatively assign the ejecta from this crater, which corresponds to the $c_{2}$ unit according to the geological map of Hynek and Di Achille (2017), either to the Late Noachian or to the Early Hesperian highland unit (1Nh/eHh; Tanaka et al., 2014). This units display similar characteristics to $\mathrm{mNh}$ but form plains. The $1 \mathrm{Nh}$ is rugged in places, while the eNh is generally smoother. They were both interpreted as an undifferentiated mixture of impact, volcanic, eolian, and fluvio-lacustrine materials (Tanaka et al., 2014).

\subsection{ELDs and Associated Structures}

The ELDs rest nonconformably on top of the $\mathrm{mNh}$ or $\mathrm{lNh} / \mathrm{eHh}$ units both in Kotido crater and in the nearby intercrater plains (Figure 3; Pondrelli et al., 2015) and correspond to the undivided etched unit $\left(\mathrm{HNMe}_{\mathrm{u}}\right)$ by Hynek and Di Achille (2017). They consist of light-toned deposits, dark-toned deposits, and interspersed mounds of intermediate tone, although there are differences in the geometry, texture, associated morphologies, and observable sedimentary structures between those in the crater and those on the plateau (Table 1 and Figure 4). Since this study focuses on the geology of Kotido crater, we refer to Pondrelli et al. (2015) for the detailed description of the ELDs located on the plateau. The sedimentary infill of Kotido crater (roughly $1 \mathrm{~km}$ ) is at least 100 times thicker than on the plateau where it has been estimated to be around $10 \mathrm{~m}$ (Pondrelli et al., 2015).

In Kotido crater, the light-toned deposits are well bedded (Figures 4a, 5a-5c, and 6a and Table S1), forming meter-thick layers, which are the smallest structures resolved by HiRISE images/DTMs and might correspond to single beds or most probably bedsets. We measured the thickness of some bedsets in light-toned deposits that correspond to the best exposed successions within the HiRISE based DEM (Figures 5a-5c). In particular, three sections (Figure 7d) were measured showing bedsets with a thickness roughly ranging from 0.3 to $3.5 \mathrm{~m}$ (Figure $5 \mathrm{~d}$ and Table S1). The stratigraphic relations between the sections were obtained through ordinary projection techniques, showing that the Section A is the deepest section and stratigraphically older than the other sections, while Section C is made of the youngest bedsets (Figure 7a). The bedsets' thicknesses do not show particular trends between the sections or within the individual sections but show a gross thinning upward trend in Section A and possibly Section B and a thickening upward trend in Section C (Figure 5e). However, the bedsets that can be measured are too few in number to infer reliable indicators for such trends. Layer (bedsets) attitudes were measured for these sections, and even if the measured values are too few to allow robust interpretations, it appears that slope values exceeding $5^{\circ}$ are confined either close to the crater margins (Section C) or close to mounds (Section A). These data are consistent with the visual inspection of the HiRISE image draped on the stereo pair-derived DEM (Figure 7c).

The light-toned layered deposits are fragmented into polygons on average about $5 \mathrm{~m}$ in diameter (Figures $4 \mathrm{~b}$ and $6 \mathrm{~b}$ ). Polygons of such scale and morphology have been interpreted to be desiccation cracks (El-Maarry et al., 2013) produced by of postdepositional dehydration-related contraction in sulfate sand (Chavdarian \& Sumner, 2006) or from postdepositional weathering (Chan et al., 2008). Irrespective of their origin and timing, these structures might overprint the sedimentary structures that might be otherwise visible at HiRISE 


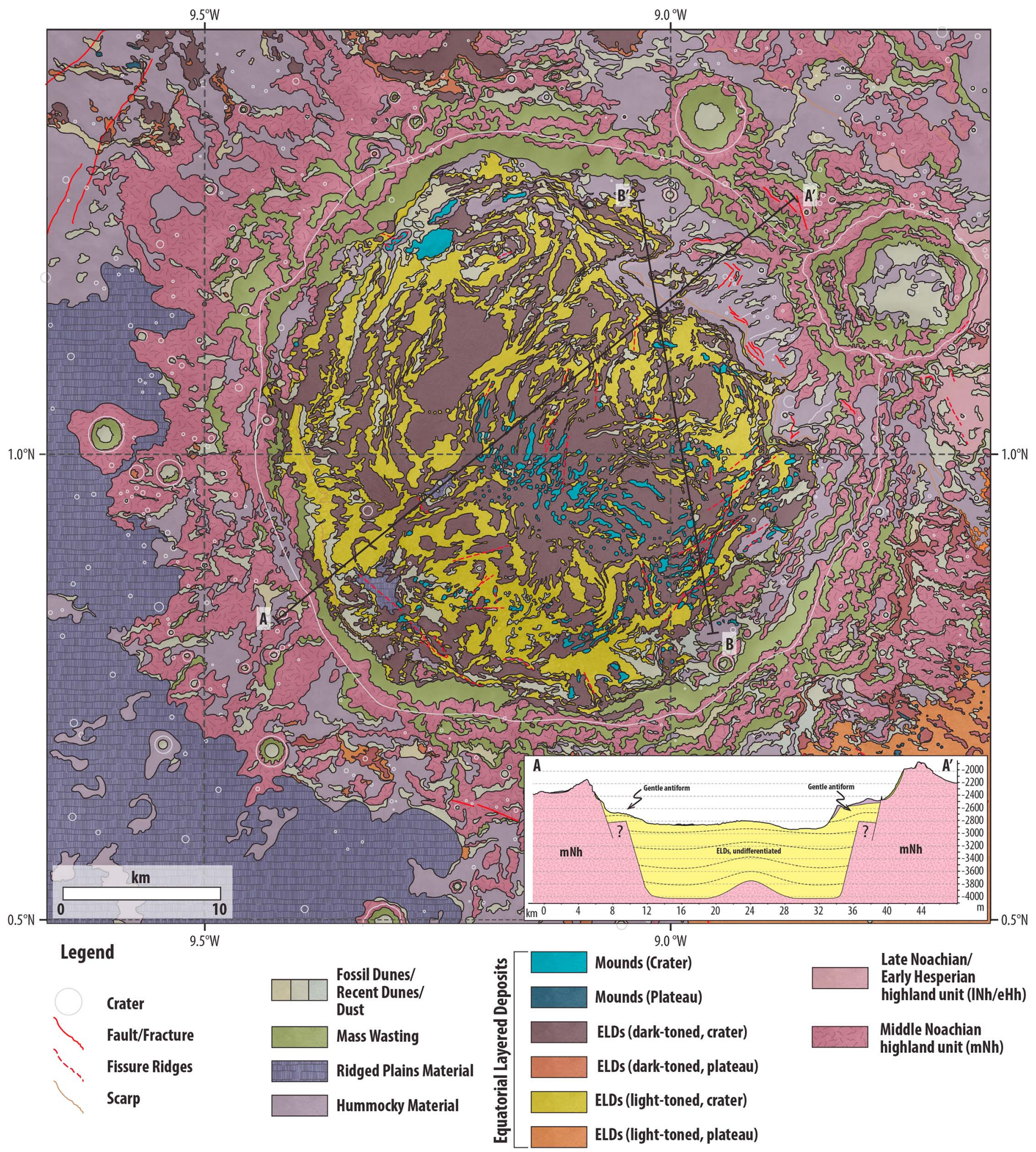

Figure 3. Geological map of the study area. The $\mathrm{AA}^{\prime}$ trace represents the location of the simplified (ELDs undifferentiated) geological section presented in the bottom right box. The section is drawn using Garvin equations to reconstruct the crater geometry. The $\mathrm{BB}^{\prime}$ trace represents the location of the section shown in Figure 6a. 
Table 1

Summary of the Stratigraphical, Morphological, and Textural Characteristics of the ELDs in Kotido Crater

\begin{tabular}{|c|c|c|c|c|c|}
\hline & & Morphological associa & ion/layers geometry & & Texture \\
\hline $\begin{array}{l}\text { ELDs (interbedded } \\
\text { light-toned deposits and } \\
\text { dark-toned deposits) }\end{array}$ & $\begin{array}{l}\text { Light-toned deposits } \\
\text { Dark-toned deposits }\end{array}$ & $\begin{array}{l}\text { Gently inclined to } \\
\text { horizontal bedding }\end{array}$ & $\begin{array}{l}\text { Mounds (locally } \\
\text { display also breccia) }\end{array}$ & Raised linear ridges & $\begin{array}{l}\text { Polygonal pattern } \\
\text { Sinuous margins Undulated surfaces } \\
\text { Quasi-circular depressions } \\
\text { Smooth texture } \\
\text { Fill and adjust the irregularities } \\
\text { of the light-toned deposits }\end{array}$ \\
\hline
\end{tabular}

scale (e.g., cross bedding such as the one documented in the nearby intercrater plain; Pondrelli et al., 2015). The light-toned layered deposits display very sinuous margins and undulated surfaces, often incised by quasi-circular depressions (Figures $4 \mathrm{~b}$ and $6 \mathrm{a}$ ). These characteristics are comparable both in shape and size with dissolution-related morphologies typical, although not exclusive, of evaporite rocks (Baioni \& Sgavetti, 2013; Goodall et al., 2000; Murana, 2018; Taj \& Aref, 2015). Eolian erosion has been invoked to explain similar morphologies (e.g., Chan \& Netoff, 2017; Hynek et al., 2003; Zabrusky et al., 2012) in the etched terrains of Arabia Terra and elsewhere. In Kotido crater, the eolian erosion is certainly important and recognizable when it generates NE trending structures such as yardangs or iso-oriented bedsets morphologies (Figure 4a). Still, bedsets do not always show iso-oriented boundaries (Figures 4a, 4b, 5b, $5 \mathrm{c}$, and $7 \mathrm{c}$ ) and sometimes show organizations and geometries whose directions are not consistent with a formation by a unidirectional NE trending wind. This suggests that at least part of these morphologies may be depositional.

The light-toned bedsets appear to be interbedded with bedsets of darker-toned deposits (Figures 3, 4a, and 4c). The extensive cover of relatively darker-toned dust and dunes does not allow observing a contiguous exposure of the stratigraphic succession. Light-toned bedsets are generally bounded by debris. This suggests the presence of a less competent interval but conceals the interval itself. Such an interval might consist of either darker-toned materials or simply light-toned materials, made less resistant to weathering and erosion because of different grain size and/or cementation. Dark-toned bedsets, where visible, show different characteristics as compared to the light-toned bedsets. They show a much smoother texture and seem to fill and adjust the irregularities left by the undulated surfaces and the quasi-circular depressions of the light-toned deposits (Figure 4c). Moreover, they appear to be more easily preserved in topographically lower and more protected parts of the basin, which suggest that they consist of relatively easily erodible materials (Figures 7d and 7e). Accordingly, even if the darker-toned bedsets might actually consist of lighter-toned materials appearing darker because of younger debris, they still show different characteristics that in turn suggest different depositional process (es) or material(s).

The layers gently drape the older succession and in the central part of the crater they appear to lie almost horizontally, although undulating at a smaller scale (Figures 4b, 5a-5c, and 7a). Two gentle antiforms are present close to the crater margins, possibly reflecting the existence of a buried terraced rim, which constrained the layers geometries (Figures 3, 7a, and 7c).

Mounds form in lateral continuity with the layered light- and dark-toned deposits (Pondrelli et al., 2015). They display a rounded geometry and sometimes an apical pit, and they consist either of poorly sorted medium-sized blocks (Bruno \& Ruban, 2016) or of layered deposits indistinguishable from the other ELDs (Figures 4c, 4d, and 9c; Pondrelli et al., 2011). These morphological/textural characteristics might help to distinguish depositional mounds from simple erosional remnants, which tend to show a preferential elongation and no difference in texture with the surrounding deposits (Pondrelli et al., 2011; Figures 7a-7d). The ELDs of Kotido crater were indeed severely affected by eolian erosion as shown by the presence of mesas, cuestas, and exposed bedsets and by the morphology of some mounds that are elongated, often consistently in clusters, in a preferential direction (Figure 8). Such patterns suggest that winds shaped the morphology of these mounds (Figures $8 \mathrm{~b}-8 \mathrm{~d}$ ). Still, while at places the morphologies displaying a preferential elongation direction are dominant or even almost exclusive (e.g., Figure 8d), in most cases the aligned mounds coexist with the circular-based and rounded mounds (e.g., Figure 8a). Circular-based mounds are the dominant mound type within Kotido crater. Unidirectional winds such as the ones that shaped the elongated mounds cannot create a rounded shape through their induced erosional processes, whereas winds coming from 


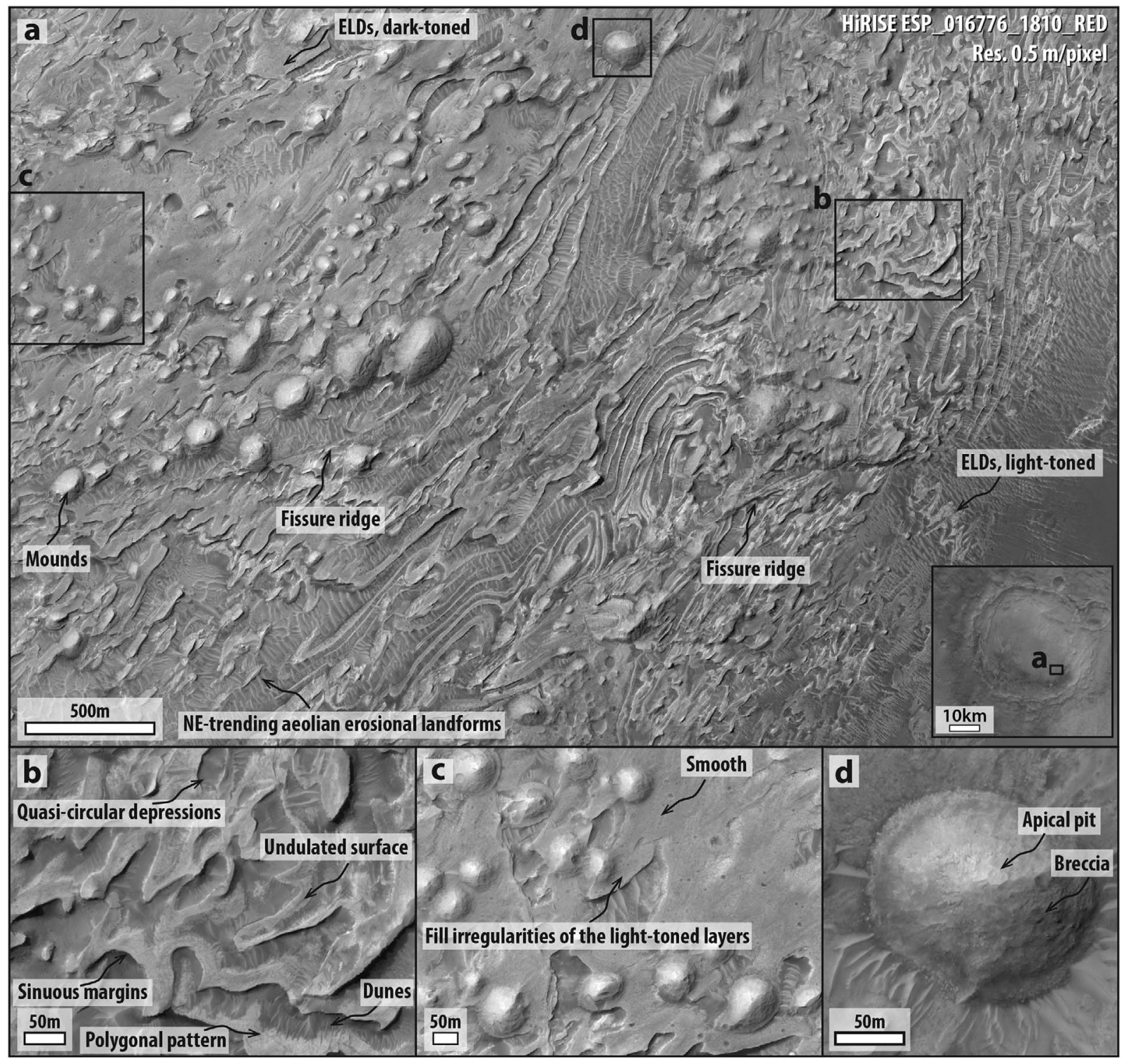

Figure 4. (a) Units forming the ELDs inside Kotido crater: light-toned deposits, dark-toned deposits, and mounds. These units are associated with fissure ridges. The boxes represent the locations of (b)-(d). Location of (a) is shown in the bottom right inset. North is up. (b) Detail of the light-toned ELDs deposits. The bedsets display sinuous margins, and their surface is undulated. Frequent 10- to 30-m large quasi-circular depressions cut these deposits, which are also affected by a meter-scaled polygonal pattern. The polygonal pattern is shown in higher resolution in Figure 6b. (c) Detail of the dark-toned ELDs deposits. These deposits appear smoother than the light-toned ones and appear to fill the irregularities left by the undulated surfaces and the quasi-circular depressions of the light-toned deposits. (d) Detail of a mound. Mounds display a rounded geometry and sometimes an apical pit and medium block-sized sediments.

different directions form multiple flat surfaces (e.g., Várkonyi et al., 2016). In addition, the erosion on a horizontally bedded succession should create a stair-stepped profile or at least be characterized by a very steep windward side and gradual gently dipping lee sides (e.g., Pelletier et al., 2018). Instead, the mounds showing preferential elongation show a rounded surface and no asymmetry along the putative wind direction (profiles in Figure 8b). These geometries suggest that the lengthened mounds were shaped by winds but possibly acting on a preexisting topography. Accordingly, we consider that part of the mounds (the circular-based and possibly some of the elongated ones as well) might represent remnants of depositional landforms.

ELDs are frequently associated with linear, layered, positive relief features that appear structurally controlled and can reach kilometer scales (Figure 4a); we interpret these as fissure ridges (hereafter 


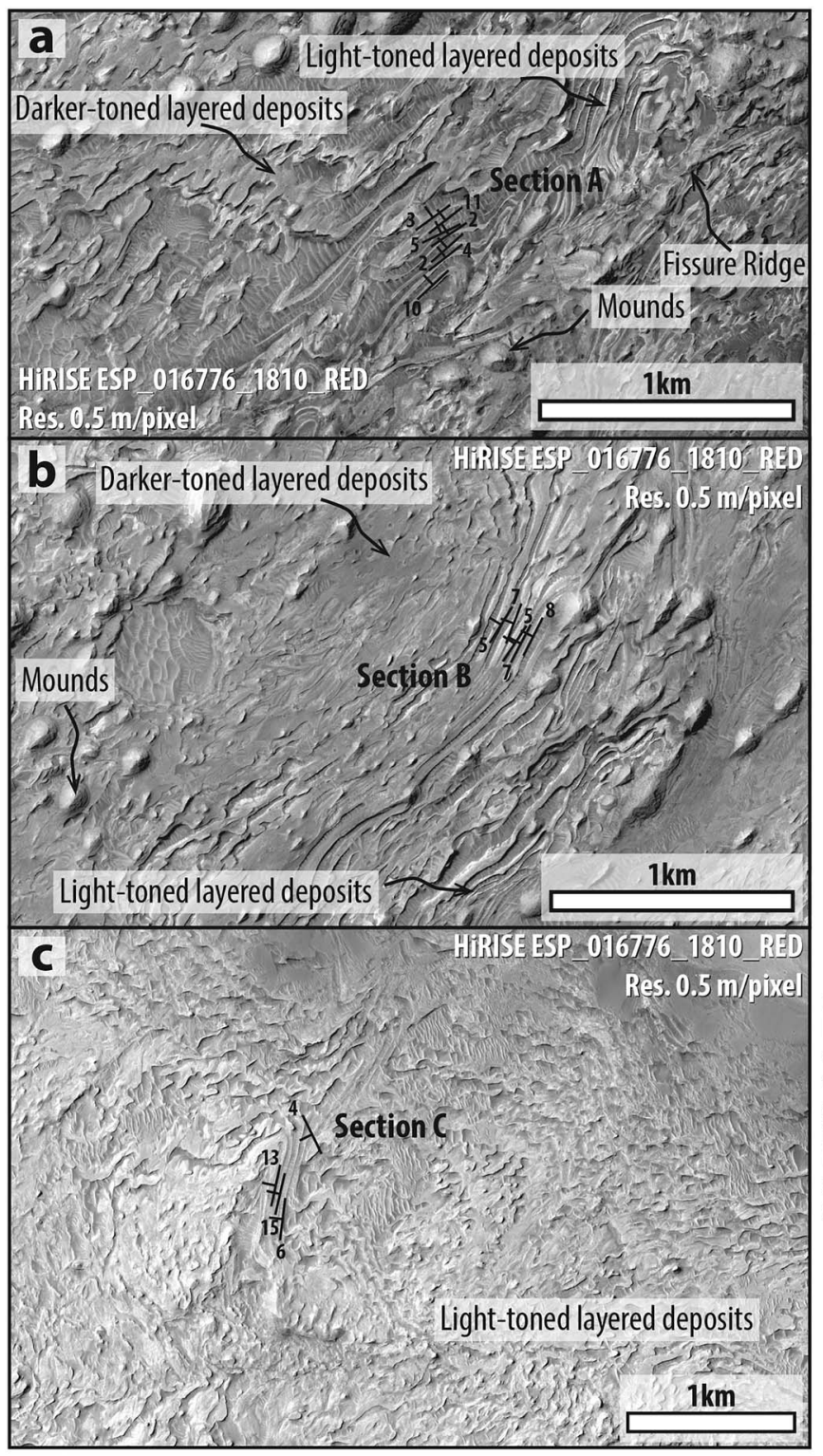

\begin{tabular}{|c|c|c|c|c|}
\hline BEDSET & ELEVATION (m) & STRIKE $\left({ }^{\circ}\right)$ & $\operatorname{DIP}\left({ }^{\circ}\right)$ & THICKNESS (m) \\
\hline Section A & -3083.929 & 233,9 & 3 & 0.847 \\
\hline Section A & -3083.082 & 232 & 11 & 0.334 \\
\hline Section A & -3082.748 & 244,2 & 5 & 1.147 \\
\hline Section $A$ & -3081.601 & 236,4 & 2 & 0.790 \\
\hline Section A & -3080.811 & 228,3 & 2 & 3.020 \\
\hline Section A & -3077.791 & 232,2 & 4 & 3.652 \\
\hline Section A & -3074.139 & 227 & 10 & \\
\hline Section B & -3057.477 & 211,9 & 5 & 1.234 \\
\hline Section B & -3056.243 & 201,2 & 7 & 1.656 \\
\hline Section B & -3054.587 & 213,7 & 5 & 1.331 \\
\hline Section B & -3053.256 & 207,8 & 7 & 1.816 \\
\hline Section B & -3051.44 & 207 & 8 & \\
\hline Section C & -2992.708 & 153,9 & 4 & 0.274 \\
\hline Section C & -2992.434 & 187 & 6 & 0.932 \\
\hline Section C & -2991.502 & 193 & 11 & 2.364 \\
\hline Section C & -2989.138 & 192,3 & 13 & \\
\hline
\end{tabular}

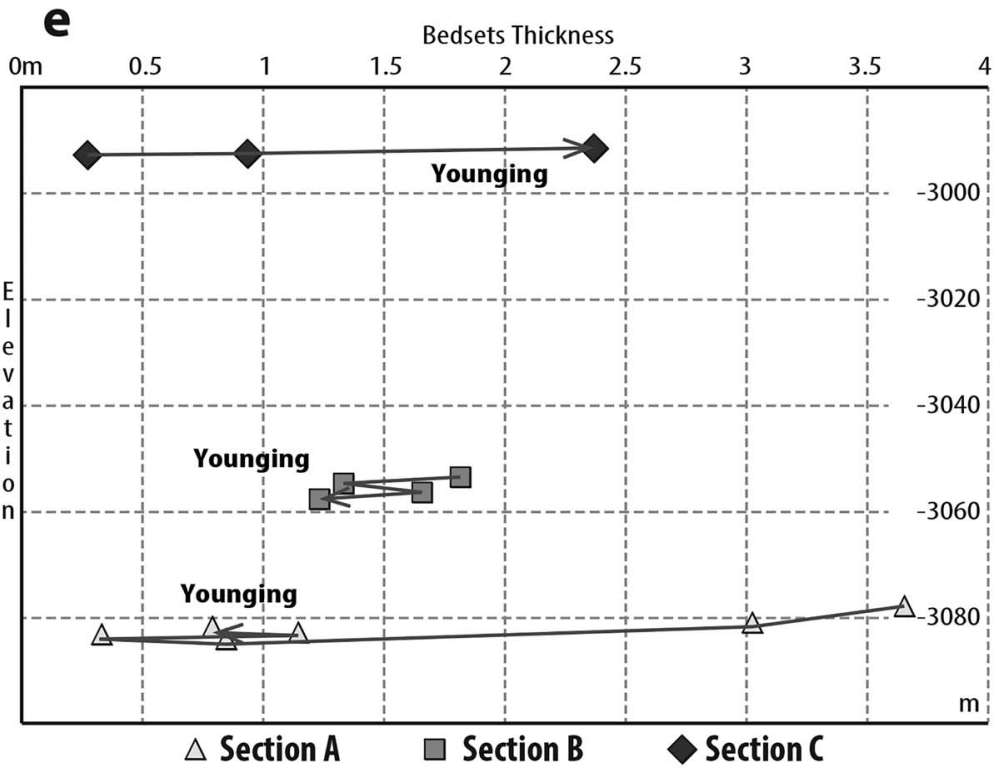

Figure 5. (a) Measured bedsets thicknesses and attitudes in section A. (b) Measured bedsets thicknesses and attitudes in section B. (c) Measured bedsets thicknesses and attitudes in section C. (d) Table showing bedsets elevation, attitudes, and thicknesses. (e) Bedsets elevation versus thicknesses graph in the different sections. Younging trends are indicated.

putative fissure ridges). Sometimes mounds (both rounded and elongated) are visible on the top of these landforms. No comparable structures/morphologies have been recognized in other mapped units. The orientation of the fissure ridges is variable (e.g., Figures $9 a$ and $9 b$ ), consistent with what is expected from an impact-related fracturing (Figure 3), and do not appear to be remnants of eolian erosion. Even if some of them were exhumed by eolian erosion, their shape suggests that they consist of materials more resistant to weathering and erosion. Fissure ridges develop when fluids flow upward through synsedimentary faults/fractures (Bargar, 1978). On Earth, they are especially common in association with hydrothermal systems and travertine deposits (e.g., Bargar, 1978; Brogi \& Capezzuoli, 2009; Capezzuoli et al., 2018). The straight shape of these structures suggests a tectonic control on their formation, and their positive topography suggests upwelling of material through faults/fractures (Figures 4a, 9a, and 9b). These characteristics are also common in clastic dykes (or injectites; e.g., Hurst et al., 2011) that form as a response to overpressure in fluid-rich materials that become fluidized and 


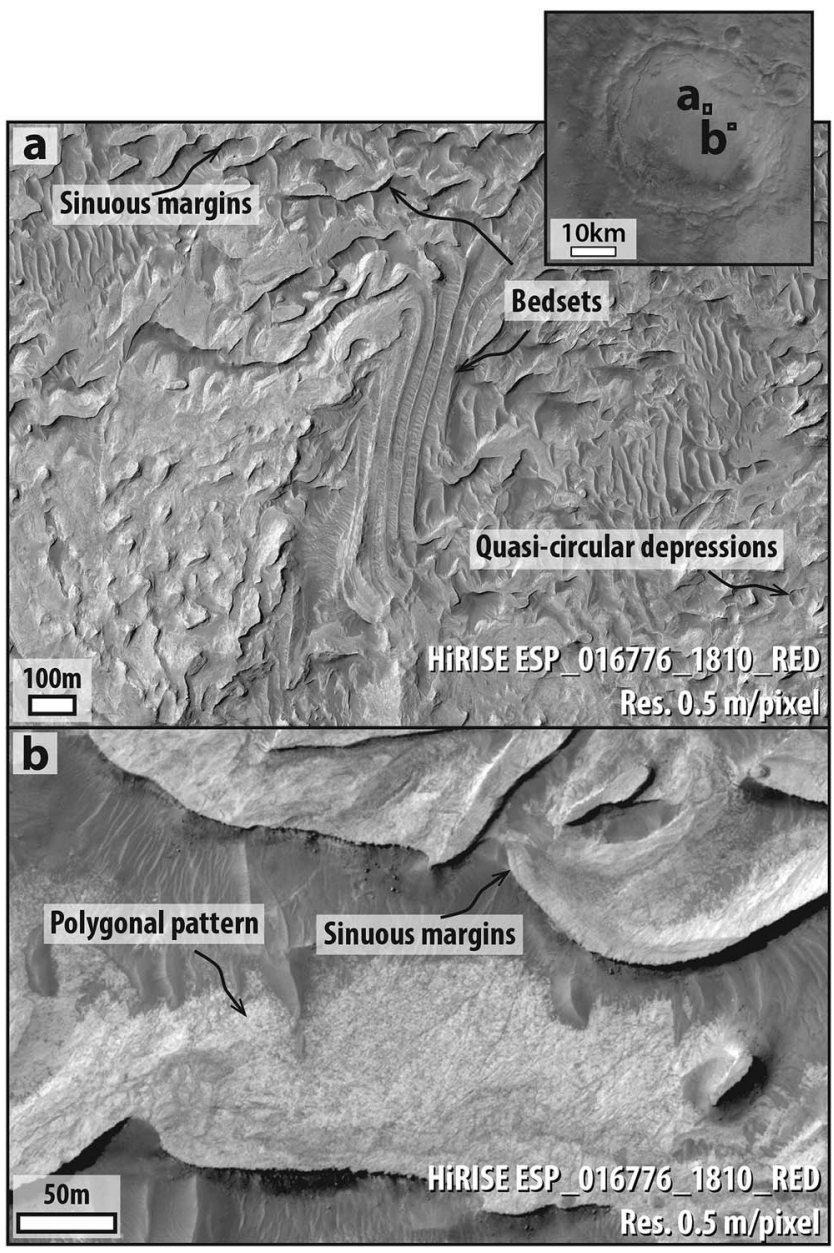

Figure 6. (a) Example of ELDs bedsets showing sinuous margins and quasicircular depressions. (b) Example of polygonal pattern. Location of (a) and (b) is shown in the top right inset. move into younger strata, thus creating a network of intrusions forming different geometrical patterns. Although difficult to discern, given the available data set, between processes that are very similar, we favor the hypothesis of a formation as fissure ridges. Clastic dykes are indeed expected to consist of different materials from the host deposits and frequently show a highly irregular geometrical pattern (Hurst et al., 2011), none of which were observed in the structures of Kotido that display a straight geometry, trend at high angles with respect to the bedding and appear to consist of the same material as the ELDs. Nevertheless, it cannot be excluded that they consist of ELDs belonging to the lowermost part of the stratigraphic column. Even if a formation as fissure ridge appears more consistent with the observations, the evidence is therefore not fully diagnostic. In any case, these structures suggest some upward movement, either of clastic fluidized material or salts-rich fluids. Locally, these structures were found associated to mounds (Figures 4a, $5 \mathrm{a}, 7 \mathrm{a}, 7 \mathrm{c}$, and $9 \mathrm{~b}$ ), which may suggest a genetic association between the two morphologies.

The mineralogical composition of the ELDs was analyzed using the CRISM observations FRT16C56 and FRT170B5 (Figure 1b). The poor quality of these observations did not enable a confident detection of hydrated material, but considering that polyhydrated sulfates were detected in the surrounding ELDs showing similar morphologies (Pondrelli et al., 2015), ELDs in Kotido crater could correspond to sulfates as well. Any difference in mineralogical composition between the dark-toned and the light-toned ELDs cannot properly be investigated using the available CRISM observations because CRISM observations do not have a high enough resolution. On the surrounding plateau, ELDs are extensively present southeast of the crater, mostly occurring in patches (Figure 3). Light-toned, dark-toned deposits and mounds can be observed here as well. Still, due to their poor exposure, their textural characteristics, as well as the association with landforms, and the possible presence of sedimentary structures cannot be observed. Several kilometers south-southeast of Kotido, ELDs have been shown to occur in correspondence of dune forms and to form meter-scale cross beds. This is suggestive of eolian transport and of a flat-lying to faintly bedded deposits, interpreted as playa deposits (Pondrelli et al., 2015). They correspond to the upper etched unit $\left(\mathrm{HNMe}_{3}\right)$ of Hynek and $\mathrm{Di}$ Achille (2017).

\subsection{Units Postdating ELDs}

The hummocky material is stratigraphically above the ELDs with a disconformable contact (Pondrelli et al., 2011, 2015). This unit consists of dark-toned and smooth materials with gently undulated surfaces that resemble hummocks and swales. Where this unit is subjected to eolian erosion, the resulting material forms dunes, suggestive of a grain size roughly confined between fine sands and granules (Bridges \& Ehlmann, 2018). The hummocky material is mostly located in topographic lows.

The ridged plains material (Scott \& Tanaka, 1986), equivalent to the plains unit (Hp) of Hynek and Di Achille (2017), rests unconformably on top of the ELDs and hummocky material in the southwestern part of the mapped area (Pondrelli et al., 2015). It consists of flat and rough surfaces consisting of competent material. This unit is widespread outside of Kotido, but in two patches inside the crater we mapped a unit with similar characteristics (Figure 3). Although the areal extension of these patches is too small to allow proper comparison, we tentatively attribute them to the ridged plains material.

The stratigraphic succession is capped by mass wasting deposits, mostly occurring on the crater slopes, and by eolian deposits, including lithified and recent dunes and dust deposits. 


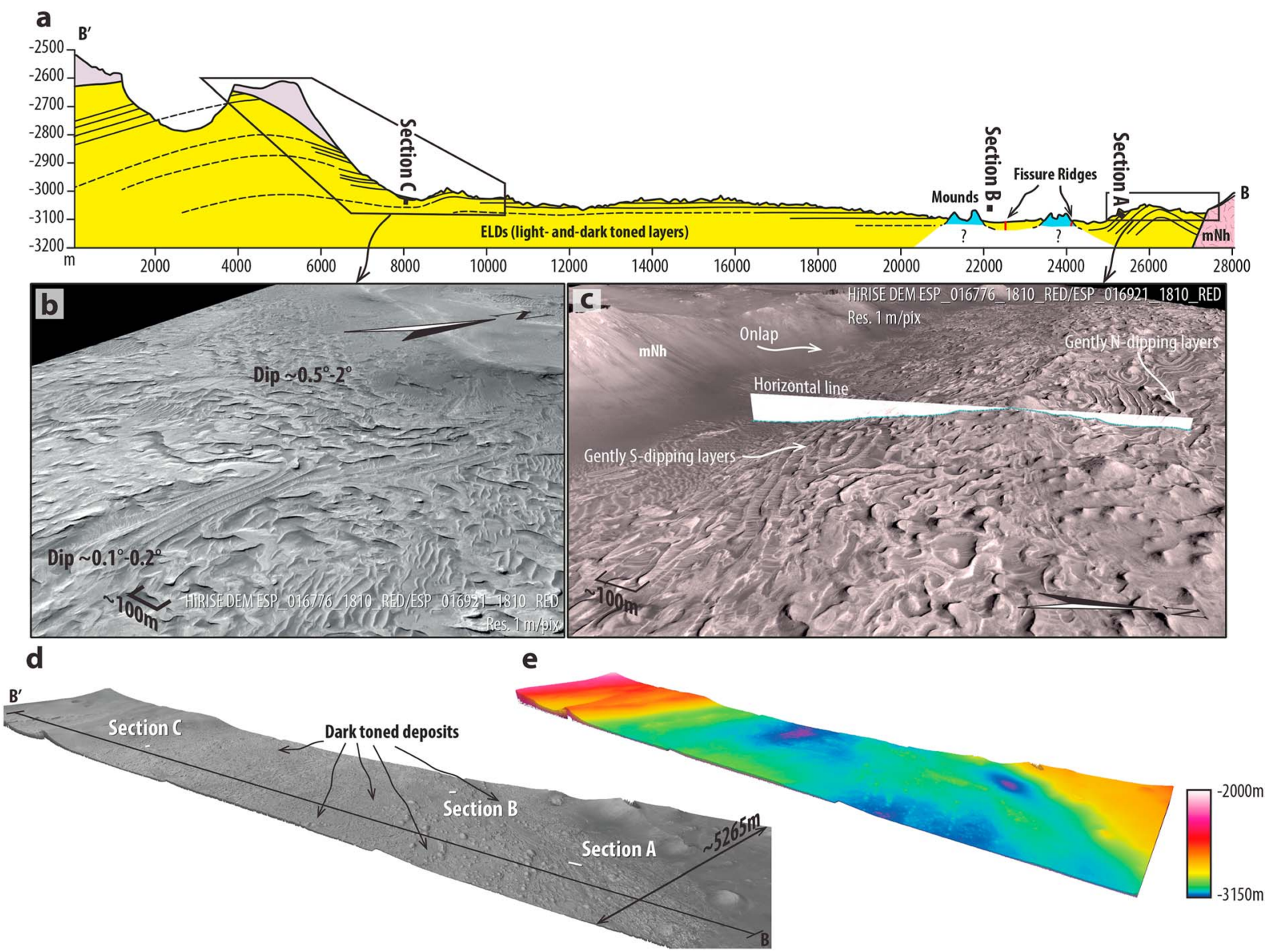

Figure 7. (a) Geological section through Kotido crater realized in the area covered by the HiRISE stereo pair ESP_016776_1810_RED/ESP_016921_1810_RED derived DEM (resolution: $1 \mathrm{~m} /$ pixel; see Figure 3 for location). Layers drape and onlap the crater deposits. The position of the measured bedsets sections is projected in order to infer their relative stratigraphic position. (b) Perspective view showing the layer geometry in the northern crater margin where layers are gently folded forming an anticlinal structure shifting to roughly horizontal layers toward the deepest part of the crater. (c) Perspective view showing a gentle anticline forming in the southern part of the crater. Bedsets onlap the crater margin. (d) Perspective view showing HiRISE image ESP_016921_1810_RED draped over the HiRISE based DEM. The location of the measured bedsets is shown. The ELDs dark-toned deposits appear to be distributed especially in the deepest parts of the crater as it is emphasized in (e) by the same color-coded image/DEM.

\section{ELDs Depositional Environments and Basin Evolution}

\subsection{Proposed Conceptual Model}

We interpret the depositional environments of the ELDs in Kotido crater as a combination of spring mounds and playa precipitation alternating with clastic transport phases and/or residual materials formed by evaporite dissolution (Figure 10). Most of these processes would have sourced from groundwater. Salt-rich fluids would have been sourced from a pressurized aquifer through fissure ridges and mounds to deposit clastic materials or precipitate evaporites immediately along the mounds' flanks or more distally forming the layered deposits (Pozzobon et al., 2019). Groundwater seepage might also have occurred in the deepest parts of the basin. Fluid expulsion processes are documented on Earth in a multitude of sedimentary settings when pore gas and/or fluids within subsurface sediments are overpressurized (e.g., Van Rensbergen et al., 2003). If the pore pressure is not dissipated through the sediment, it generates upward oriented escape paths or uses preexisting fractures that can reach the surface (Allen et al., 2013; Van Rensbergen et al., 2003).

The extensive presence of fissure ridges and mounds (Figures 4a, 4d, and 9a-9c) points toward subsurface upwelling and on a larger scale may explain the different thickness and geometries between the ELDs located in the different craters and on the intercrater plains (Cadieux \& Kah, 2015; Pondrelli et al., 2015; Schmidt et al., 2018). Fissure ridges represent structurally controlled kilometers-long topographically 


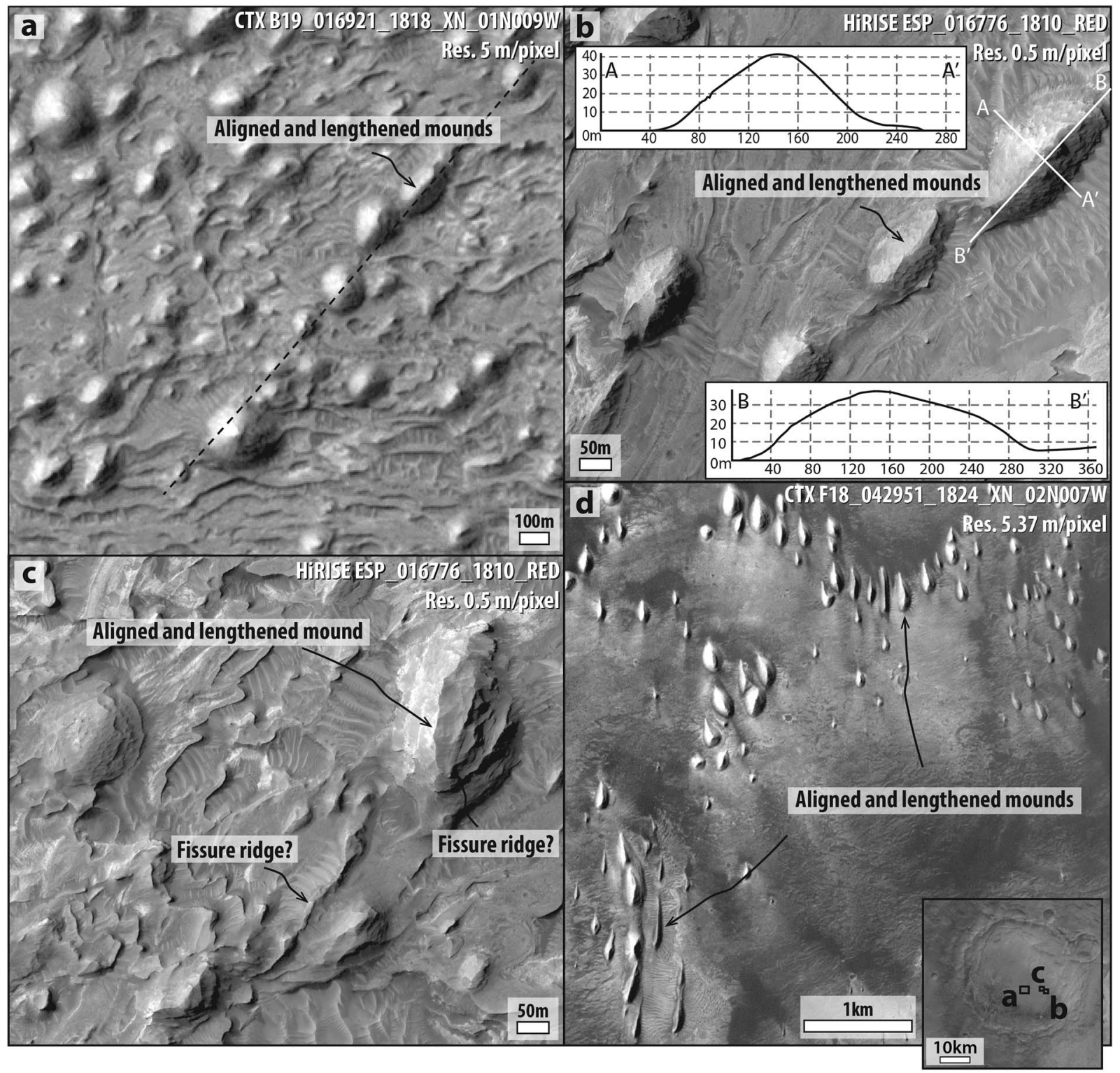

Figure 8. Eolian erosion shaping lengthened and sometimes aligned mounds (see the bottom right box for location of a to c). (a) Aligned rounded-shaped and lengthened mounds. (b) Aligned and lengthened mounds. The profiles show the geometry of the lengthened mound (based on HiRISE DEM). (c) Aligned and lengthened mounds associated with some possible fissure ridges. (d) Aligned and lengthened mounds (see Figure 10a for location).

high-standing features made of layered deposits and in some cases exhibit mounds on their tops (Figures 4a, 9a, and $9 \mathrm{~b}$ ). Their morphologically distinct characteristics, emphasized by the straight alignment of ELDs, suggest that they were a source for fluids that led to ELDs precipitation or at least cementation. These structures are widespread in surrounding craters such as Vernal (Allen \& Oehler, 2008), Crommelin (Franchi et al., 2014), and Firsoff (Pondrelli et al., 2015), as well as in the intercrater plains (Edgett \& Malin, 2000). In Kotido crater they generally show either a roughly radial or circular distribution (Figure 3), which suggests that they were at least in partially influenced by the faults/fractures associated to the crater formation. Mounds have been interpreted as the results of fluid expulsion in other places in Arabia, either as clastic (Pondrelli et al., 2011) or evaporitic processes (Allen \& Oehler, 2008; Franchi et al., 2014; Pondrelli et al., 2015) because of their conical shape, the presence in certain cases of an apical pit and because of their texture: they consist either of medium-blocks-sized breccia or of layered deposits that bend upward toward the mound (Pondrelli et al., 2015). In Kotido crater they are mostly 


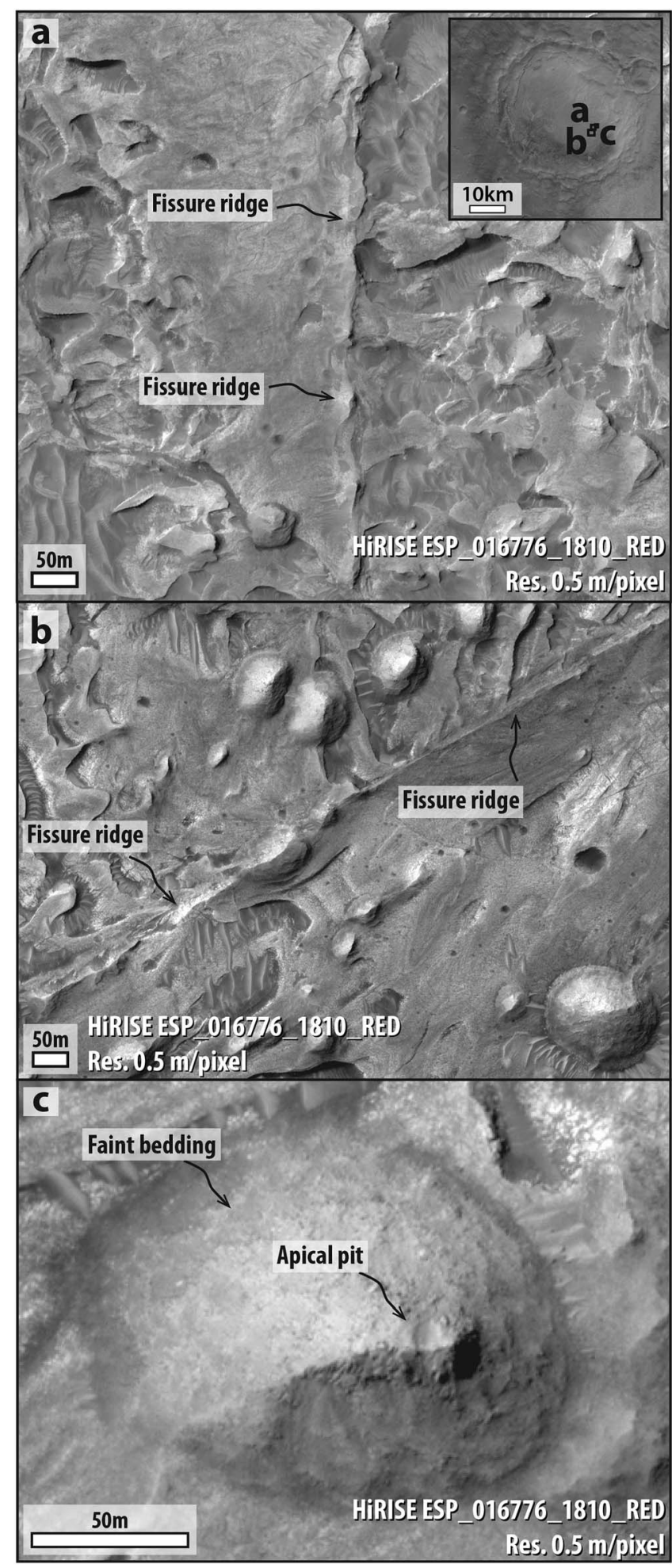

Figure 9. Examples of putative fluid expulsion features (HiRISE image ESP_016776_1810_RED, res. $0.5 \mathrm{~m} / \mathrm{pixel}$ ). Location of (a) is shown in the top right inset. North is up. (a) N-S trending fissure ridge. (b) NE-SW trending fissure ridge with mounds emplaced over it and around it. (c) Mound showing an apical pit, a poorly sorted medium to coarse block sized texture, and some faint bedding. concentrated in the central part and along the margins of the basin (Figure 3), generally in clusters, sometimes in rows and sometimes aligned along fissure ridges (Figures $4 a, 4 c$, and 9b).

\subsection{Possible Alternative Scenarios}

Since the ELDs are generally subjected to severe wind erosion, as it is suggested by the extensive presence of yardangs (e.g., Fueten et al., 2017), it is critical to understand whether these are truly depositional landforms or simply the product of differential erosion shaping originally much more extended deposits (e.g., Bennett \& Bell, 2016; Day et al., 2016). This in turn reflects the more general problem of estimating the EDLs original extent and how much has been removed by eolian erosion. The answer to this question has deep implications for the interpretation(s) of their depositional environment(s). The geometry and thicknesses of the ELDs in different basins (both in craters and intercratered areas) are different from each other (Cadieux \& Kah, 2015; Pondrelli et al., 2015), which suggests different accommodation spaces. Again, this might be controlled during the deposition (different sedimentary thicknesses and geometries) or during the erosional stage (different preservation potential depending on the physiographic conditions). Erosion has been invoked to shape originally uniform ELDs materials to their present patchy distribution (e.g., Andrews-Hanna et al., 2010; Hynek \& Di Achille, 2017; Malin \& Edgett, 2000; Michalski \& Niles, 2012). Under such scenario, eolian dunes and/or dust (Bennett \& Bell, 2016; Michalski \& Niles, 2012; Tanaka, 2000) or pyroclastic materials (Hynek et al., 2002; Kerber et al., 2012; Scott \& Tanaka, 1982) might have been cemented by rising groundwater (Andrews-Hanna et al., 2007, 2010; Andrews-Hanna \& Lewis, 2011; Grotzinger et al., 2005; Hynek \& Di Achille, 2017; Murchie et al., 2009; Zabrusky et al., 2012). Groundwater would have provided the possibility to preserve the sedimentary materials that are located under the water table whereas the loose materials above were preferentially subjected to erosion. Similar to the scenario depicted in Figure 10 where groundwater represents the most important control of the system, except that in this case groundwater would have controlled the preservation rather the deposition. The ELDs would thus represent a laterally uniform deposit, regardless of their physiographic location.

Ideal mounds that show conical morphologies consist of breccia at least in their central part and display an apical pit that strongly suggests a depositional origin (Pondrelli et al., 2011). Unidirectional eolian erosion always shows some preferential elongation and cannot produce perfectly rounded structures (Figures 8a, 8b, 8d). Moreover, sometimes mounds that display preferential elongation also show straight topographically raised features that might represent fissure ridges (Figures $8 \mathrm{~b}$ and $8 \mathrm{c}$ ). This might suggest that the eolian eroded materials originally had a different resistance to weathering and erosion. In Firsoff crater, some layers have been shown to bend upward toward the mounds (Pondrelli et al., 2011, 2015). However, where HiRISE images are not available, the textural observations and the geometry of the layers cannot be properly evaluated (folding layers need a HiRISE-based DEM and a good layer exposure). So in these cases if the apical pit is not present (which may be simply because they are covered by other sediments or eroded), then the general conical morphology represents the only element to distinguish between depositional and erosional features. However, at least some 


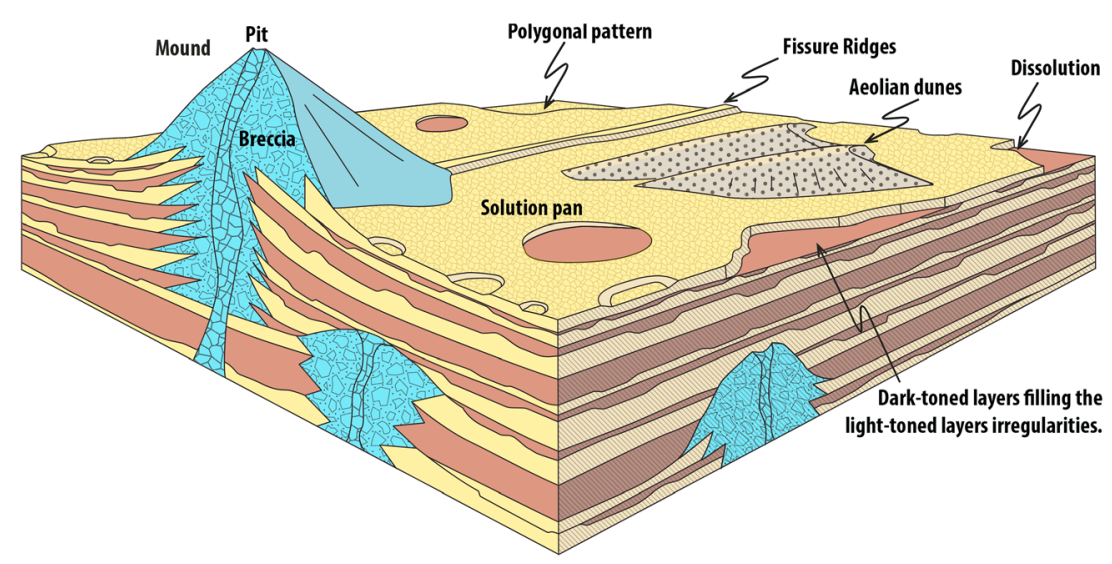

Figure 10. Conceptual geological model of the ELDs genesis in Kotido crater. The source of the fluids rests in the groundwater, and fluid upwelling occurs through fissure ridges and spring mounds. The layered deposits consist of light-toned and darker-toned bedsets both sourcing from the same conduits. We interpret the light-toned bedsets as formed by evaporitic processes and the darker-toned as related to clastic deposition.

mounds appear to show all the morphological and textural characteristics to suggest a depositional origin linked to fluid expulsion processes (Figures 4d and 9c; Pondrelli et al., 2011).

ELDs have been shown to consist of different morphologies, textures, and sedimentary structures in different settings (Murana, 2018; Pondrelli et al., 2015). In particular, in the intercrater plains south of Kotido crater they occur in dune forms with meter-scale cross bedding (Pondrelli et al., 2015). Such morphologies/sedimentary structures have not been detected within Kotido crater, indicating lateral variability among the ELDs. In turn this variability would suggest a system of interconnected depositional environments rather than a spatially uniform fall out of dust/pyroclastic materials.

\subsection{Geological Context}

In order to put our results into a broader geological context, a couple of unnamed hourglass-shaped craters located less than $65 \mathrm{~km}$ east of Firsoff crater were analyzed (Figure 11a). Pondrelli et al. (2015) mapped this area showing that both craters contain an infill of ELDs and general characteristics similar to Kotido (Figures 11b-11d). The northernmost crater is almost entirely filled with ELDs that cover nearly the entire southern rim, onlapping against the $\mathrm{mNh}$ unit, which includes the craters rims (Figures 11a and 11c). The ELDs also cover also the northeastern part of the crater rim (Figures 11a and 11e). Here they show a fan-shaped morphology that resembles features such as crevasse splays or washovers (Figures 11a and 11e), suggesting that the ELDs debouched northward from the filled crater to the plateau, not by breaching the rim but simply overstepping it. During this scenario, the ELDs would have filled the northernmost crater and then debouched northward across the intercrater plains. Salt-rich fluids leading to almost immediate precipitation of evaporites would explain the lack of channels within the fan-shaped deposits of Figure 11e and also the lack of channels and deltas within the deposits of Figure 11c. Still, the fan-shaped morphology might also represent ELDs that originated on the plateau and were remobilized into the craters or simply an erosional remnant of a previously much more laterally extended deposit.

To redeposit ELD that were originally emplaced on the plateau into the craters would imply at least a partially clastic-dominated fluvio-lacustrine depositional system. The material would have been transported through clastic processes to finally settle in the craters through clastic and/or evaporative processes. Such a scenario would explain the difference of stratigraphic thickness between the successions located in the plateau (partially erosional domain) and the craters (depositional domain). However, it is not supported by the paucity of channels in the nearby intercrater plain or by the fact that the crater rims are generally unbreached (e.g., Kotido and Firsoff craters). Figure 11c shows the transition between the craters where there is no evidence of channels and/or deltas that would support a fluviolacustrine scenario. 


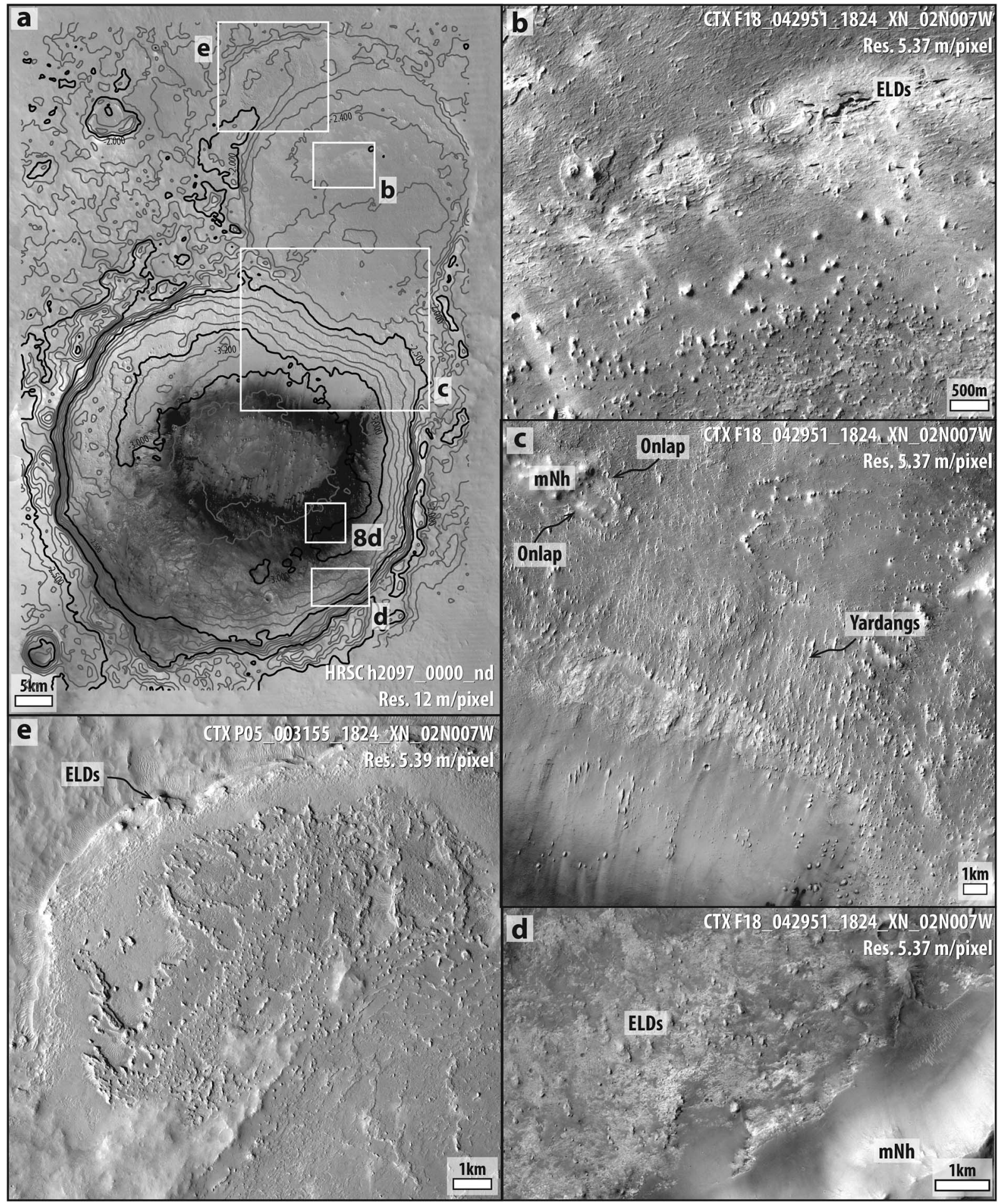

Figure 11. (a) Unnamed hourglass-shaped craters located less than $65 \mathrm{~km}$ east of Firsoff. North is up. Both craters show an infill made by ELDs as it is shown in (b) and (d). The northernmost crater is almost filled by the ELDs that cover almost entirely the southern part of the rim (c). In the northwestern part of the crater, the ELDs appear to breach the rim and debouch in the plateau (e). Location of (a)-(e) and Figure 8d is shown. Contour lines are $100 \mathrm{~m}$ spaced. (b) ELDs in the northernmost crater. (c) Passage between the northern and the southernmost craters. Eolian erosional features are widespread. (d) ELDs in the southernmost crater. (e) ELDs sourcing from the crater to the plateau. 
The possible formation of the fan-shaped morphology depicted in Figure 11e as an erosional remnant reflects the more general possibility that ELDs originally represented a much larger depositional body and distributed both in the craters and on the plateau (Andrews-Hanna et al., 2010; Andrews-Hanna \& Lewis, 2011; Michalski \& Niles, 2012; Zabrusky et al., 2012; Michalski et al., 2013; Hynek \& Di Achille, 2017). Again, this scenario would imply a consistent lateral uniformity of the deposits in terms of morphological association and textural characteristics, but the duneforms made of meter-scale high-angle cross bedding found in the intercrater plain just south of Kotido appear to be different from the ELDs located inside the craters (e.g., Figures 4a, 4b, and 8b-8d). Moreover, meter-scaled cross bedding suggests tractional transport in an eolian depositional setting (e.g., Reading, 2009). High-angle cross bedding is not consistent with dust-air fall deposition, while pyroclastic deposits generally form low-angle cross bedding from antidunes (e.g., Reading, 2009).

Erosional processes affecting materials with similar geological properties and groundwater protecting the lower parts from erosion through cementation and/or evaporite precipitation are expected to produce planar surfaces (Stokes surface; Fryberger et al., 1988). This surface (or surfaces if more groundwater fluctuations are recorded) would correspond to the groundwater level marking the erosion of the uppermost loose materials and the preservation of the lowermost cemented deposits. Even if the material below these surface(s) was obviously subjected to erosion as well, the different erosional rates should still be recognizable, especially at a regional scale, with the development of large flat surfaces and terrace-like platforms.

Probably our study area is not large enough to address this issue, but the maximum elevation of the ELDs in the northernmost crater does not correspond to the maximum elevation recorded in the terrace-like features bounding the southernmost crater (Figure 11a). Terrace-like platforms are also present around Kotido but without the lateral continuity that a Stokes surface is expected to generate (Figure 3). Moreover, in Kotido crater the bedsets' attitudes appear to be consistent with a formation of these platforms as a response to the original crater morphology (Figure 3, section AA'), rather than suggesting a portion of a once extensive preservation surface. Furthermore, the volume of eroded material would be (not so much in Kotido, but especially in bigger craters such as FIrsoff or Crommelin) huge (Zabrusky et al., 2012).

In any case, the sedimentary thickness appears to be controlled by the different accommodation space within the different craters and intercrater plains, whereas the base level controlling the accommodation space is given by the groundwater and its fluctuations through time. Regardless of the depositional processes, that is, whether the groundwater provided salt-rich fluids to precipitate evaporites or favored lithification of previously deposited materials, it appears that the groundwater acted as the main control on ELDs deposition and/or preservation.

An important role of groundwater in ELDs deposition in Arabia Terra was already suggested for the case of sulfate-bearing materials (Andrews-Hanna et al., 2007, 2010; Allen \& Oehler, 2008; Rossi et al., 2008; Andrews-Hanna \& Lewis, 2011; Pondrelli et al., 2015, 2011; Michalski et al, 2013; Franchi et al., 2014) and for the clay-bearing materials located in the deepest craters of Arabia Terra (Salese et al., 2019). In the specific case of the study area, groundwater might have acted by providing pressurized fluids rich in salts, gas, or sediments, which led to water upwelling and evaporite precipitation, and/or the emplacement of mud volcanoes. Alternatively, groundwater might have provided fluids rich in salts to favor the diagenesis of already deposited clastic sediments. In this latter case, sediments might have been deposited through eolian, dust/air fall, or volcaniclastic processes. Still, this formational process would imply much more laterally and vertically relatively uniform textural and morphological characteristics, which contrast with the observed variability and morphologies such as mounds and fissure ridges (Figures 4 and 9).

The different characteristics of the light- and darker-toned deposits suggest different emplacement processes. Light-toned deposits show textures, sedimentary structures (i.e., the polygonal cracking pattern) and are associated with morphologies indicative of an evaporitic depositional process. In particular, the quasi-circular depressions and the rounded and/or rimmed margins suggest a formation through dissolution process, typical, although not exclusively, of evaporitic rocks (Baioni \& Sgavetti, 2013; Murana, 2018). The polygonal cracking pattern in analogue terrains has been interpreted to have been formed by large desiccation cracks (El-Maarry et al., 2013), which is also consistent with the presence of evaporites. Similar to the quasi-circular depressions and the rounded and/or rimmed margins, polygonal cracking 
is not exclusive of evaporites. Chavdarian and Sumner (2006) interpreted it to result from postdepositional dehydration-related contraction in cemented sulfate sandstone and Chan et al. (2008) to postdepositional weathering. Moreover, polygonal cracking is very typical in clay-bearing deposits on Mars (e.g., Bishop et al., 2008; Le Deit et al., 2012). Nevertheless, the mutual association of morphologies and structures is consistent with the presence of rocks with an evaporitic content. Moreover, clay-bearing deposits commonly display polygonal cracking but not quasi-circular depressions. A formation by postdepositional weathering is likely characterized by cracked/fractured margins, whereas the layers appear smooth and rounded.

The darker-toned deposits show much smoother textures and appear to fill the irregularities of the lighttoned deposits. They are generally either covered by reworked eolian dune deposits showing the same texture and color, or they are located mostly in the deepest and/or more protected parts of the crater (Figures 3 and 7d). These observations suggest that these deposits consist of materials more easily eroded by eolian processes (i.e., relatively fine-grained and/or poorly cemented). The observable characteristics do not appear to be consistent with evaporite depositional processes.

Light- and darker-toned deposits and mounds are interbedded (Figures 12a-12c), which implies a genetic relation among them. Dark-toned bedsets are not always evident, because they are often covered by recent dunes and dust (Figure 12c). We interpret the landforms depicted in Figure 12a as embedded mounds because they show the presence of block-sized materials and because of their rounded shape. No unidirectional wind can produce such a shape, even less so within a specific stratigraphic interval as the case of Figure 12a. Moreover, the visual inspection of layer attitudes using HiRISE-based 3-D reconstructions shows that layers dip shallowly in opposite directions on either side of the mounds (Figures 12b and 12d). We need to be very cautious with these scattered observations because HiRISE DEM coverage and bedsets' exposure do not allow us to constrain them consistently over the study area. However, when the mounds are far from the crater rims such as in Figure 12, the gentle anticlines that form might be the result of higher depositional rates associated with the mounds, whereas the gentle antiforms forming close to the crater rims might be inherited by the topography of the crater that the layers drape. Still, the possibility that these structures are tectonic, similar to collapse structures, cannot be ruled out.

Alternating light- and darker-toned deposits suggest changes in the depositional processes. The characteristics of light-toned bedsets point toward an evaporite deposition, while darker-toned bedsets may reflect clastic and/or residual depositional or postdepositional processes, respectively. The lateral and vertical association of these deposits with fluid expulsion features such as mounds and fissure ridges suggest that the evaporite deposits were derived by sulfate-rich fluids that were sourced from the groundwater and then precipitated either on the flanks of the mounds or around them, forming flat-lying layers draping the basin. The darker-toned deposits might represent clastic products of fluid expulsion, possibly associated with phases richer in water that did not allow precipitation. Under such a scenario, coarser-grained materials would be constrained close to the source areas (fissure ridges and mounds) and finer-grained materials would settle throughout the basin. Clasts would source from deeper parts of the stratigraphic column either with or without postdepositional mineral transformation. The resulting, possibly cyclic, depositional pattern would in some way be similar to the one found in terrestrial playa deposits (e.g., Handford, 1982), although in that case the water source would have come from surficial drainage processes. Alternatively, darker-toned deposits might correspond to completely different processes than the light-toned ones, such as the fall out of dust during dry phases cemented by the following stage of water table rising. This would also explain the cyclic light-dark pattern. These deposits might also represent, entirely or in part, the residual products (i.e., the deposition of remobilized weathering products and the indirect accumulation of insoluble materials) of the solution processes affecting the lighter-toned materials (e.g., Bruthans et al., 2009).

This interpretative scenario raises issues about the mechanisms, which favored groundwater upwelling, and include either a regional or a catastrophic control. In the first scenario, possibly climatic-driven groundwater fluctuations led to phases of fluid upwelling through preexisting (regional and/or impact crater-related) faults/fractures systems. In the catastrophic scenario, groundwater upwelling would be made possible by the impact process itself.

In the northeastern margin of Kotido crater, a wide terrace (up to $7 \mathrm{~km}$ large) is evident (Figure 3). Its lateral extension is confined just west of a roughly $10-\mathrm{km}$ large crater that impacted Kotido's rim, so that the terrace 


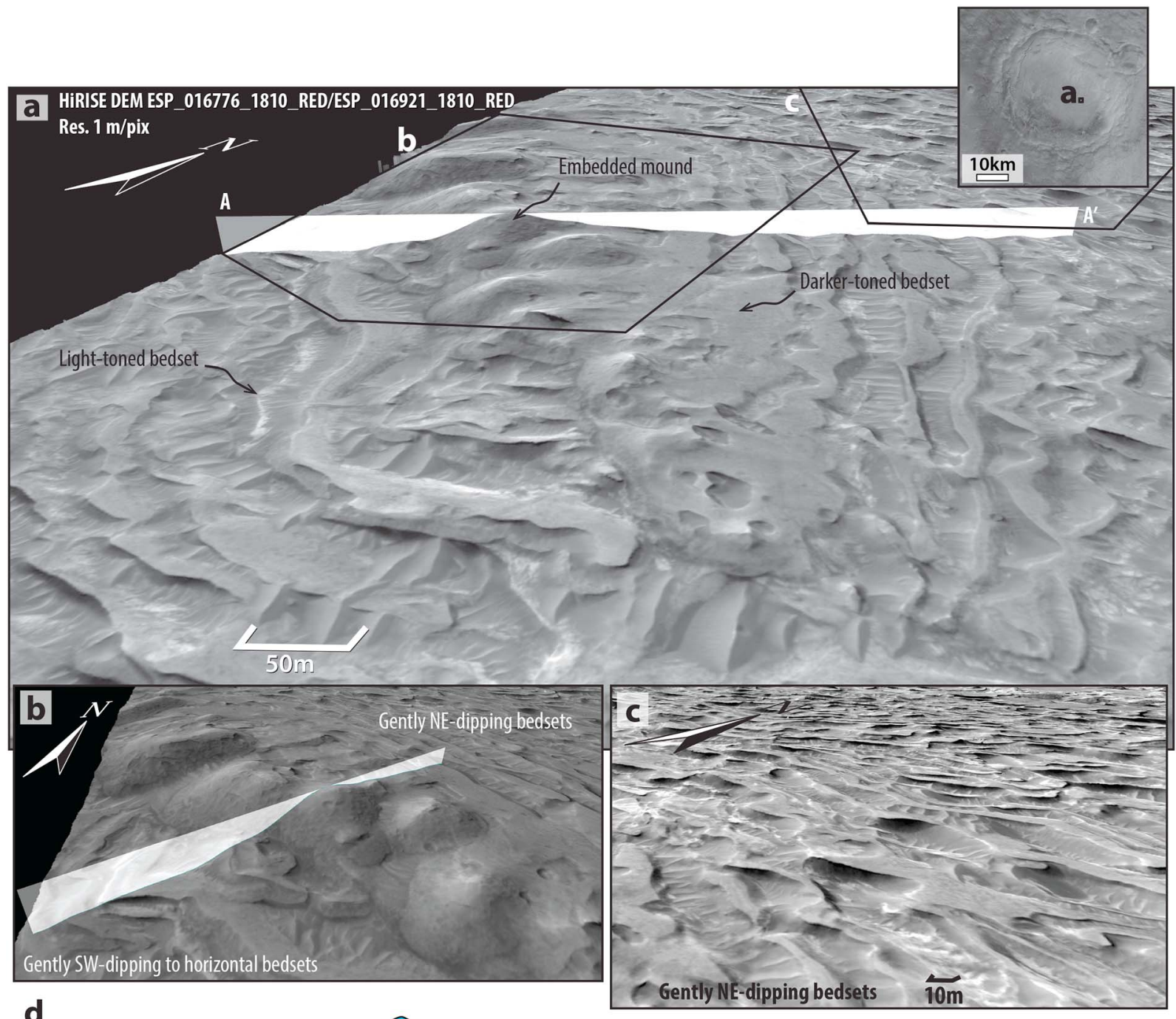

d

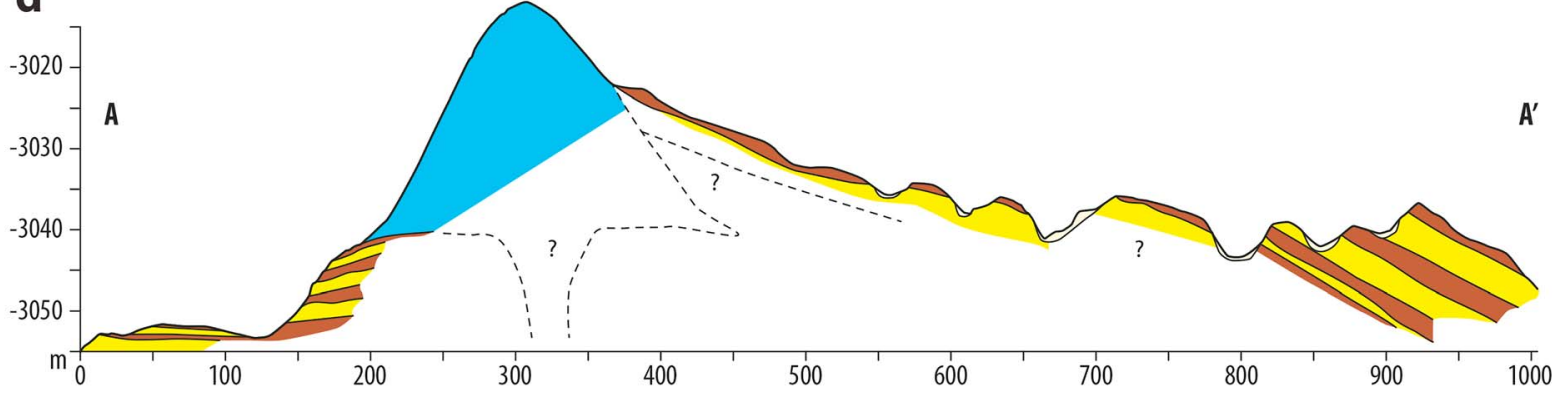

Figure 12. (a) Perspective view of the ELDs located in correspondence of the upper right inset (HiRISE image draped on HiRISE-derived DEM). Light-toned and darker-toned bedsets and mounds are interbedded and mounds are partly embayed by younger layered deposits. AA' represents the trace of the geological section of (d) with indication of the horizontal line. The black box indicates the location of (b) and (c). (b) Detail of (a) with a different perspective view to emphasize the different dip of the layers on either sides of the mounds. (c) Detail of (a) with a different perspective view to show interbedding light- and darker-toned gently dipping bedsets. (d) Geological section through the $\mathrm{AA}^{\prime}$ trace. The dimensions of the mounds and the bedsets are emphasized here together with the stratigraphic relations between the ELDs units. Dotted lines represent inferred mound morphology and layer boundary.

appears to include this small crater ejecta on which ELDs were deposited (Figure 3). ELDs appear to postdate the small crater formation because the terrace is very smooth and flat, and it extends laterally quite far from the crater, thus implying an origin not related to the crater formation. Moreover, the layers below the terrace appear to be undisturbed. This implies that ELDs deposition occurred after the small crater was emplaced, which in turn entails that ELDs deposition in Kotido is not directly connected to Kotido's impact process. 
Groundwater upwelling was most probably controlled by regional processes (e.g., climatic?). The estimates for the cryosphere depth for this area of Mars during the Noachian-Hesperian transition do not exceed a few kilometers (e.g., Clifford et al., 2010; Weiss \& Head, 2017), not far from the inferred base of many craters in Arabia Terra (including Kotido's) and probably within the reach of the fractures associated with craters formation (Pozzobon et al., 2019).

\section{Conclusions}

We analyzed the geology of Kotido crater with the aim to map the different units forming the ELDs, understand their mutual stratigraphic relations, and infer the depositional environments in which they formed. Finally, we tried to contextualize the local evolution of Kotido crater within the framework of the whole light-toned deposits of Arabia Terra.

Within the ELDs we recognized three units: light-toned deposits, darker-toned deposits, and mounds. These units are interfingered, which implies a genetical relation among them, and are frequently associated with raised linear ridges interpreted as fissure ridges. We discussed the possibility that these deposits/morphologies represent erosional remnants of laterally much more extended and uniform units instead of depositional bodies. Although erosion is shown to have heavily affected the whole ELDs, we interpret the ridges and the mounds as depositional, fluid expulsion-related features. The light-toned deposits show characteristics consistent with evaporite deposition, including the quasi-circular depressions, the undulated surface, the sinuous margins, and the polygonal pattern. In contrast, the darker-toned material accumulates to fill the irregularities of the light-toned deposits, appears much smoother than the light-toned materials, and, in general, does not show characteristics that can be linked to evaporitic processes. Hence, we tentatively interpret the darker-toned material as a result of clastic depositional processes and/or as residual deposits. The fluid expulsion processes, possibly depending on the varying relative ratio between fluid, clasts, and salts, might alternatively led to clastic deposition (darker-toned deposits) and evaporite deposition (light-toned deposits). Alternatively, darker-toned deposits might represent dust material deposited during quiescent phases of the fluid expulsion process and cemented by the following water table rising.

Acknowledgments

We gratefully acknowledge the insightful comments of David Baratoux, Kristen Bennett, and an anonymous reviewer, which helped us to improve our manuscript. We warmly thank the HRSC Co-Investigator team for the fruitful and lively scientific discussions. This work acknowledges the financial support from the Italian Ministry of University and Research for Monica Pondrelli, Région Pays de la Loire, project GeoPlaNet (convention 201610982) for Laetitia Le Deit and Francesco Salese. Francesco Salese acknowledges the Marie Curie Individual Postdoctoral Fellowship (WET_MARS, Grant Agreement 795192). Riccardo Pozzobon and Angelo Pio Rossi were supported by the European Union's Horizon 2020 research and innovation program under grant agreement 776276 (PLANMAP). All the data sets used in this manuscript can be accessed from the PDS Geosciences Node Orbital Data Explorer (ODE) (http://ode.rsl.wustl. edu/mars/). We are indebted to the U.S. Geological Survey for realizing the Integrated Software for Imagers and Spectrometers (ISIS) processing software and with the NASA AMES Stereo Pipeline that allow the processing of CTX and HiRiSE-based 3-D images.
These processes would be controlled by groundwater emplacement and fluctuations. Such dynamics might have possibly controlled by climatic changes and interactions with the fractures related to the crater formation, which allowed the actual upwelling from a pressurized aquifer.

\section{References}

Allen, C., Oehler, D., Etiope, G., Rensbergen, P., Baciu, C., Feyzullayev, A., et al. (2013). Fluid expulsion in terrestrial sedimentary basins: A process providing potential analogs for giant polygons and mounds in the Martian lowlands. Icarus, 224, 424-432. https://doi.org/ 10.1016/j.icarus.2012.09.018

Allen, C. C., \& Oehler, D. Z. (2008). A case for ancient springs in Arabia Terra, Mars. Astrobiology, 8, 1093-1112. https://doi.org/10.1089/ ast.2008.0239

Al-Samir, M., Nabhan, S., Fritz, J., Winkler, A., Bishop, J., Gross, C., \& Jaumann, R. (2017). The paleolacustrine evolution of Juventae Chasma and Maja Valles and its implications for the formation of interior layered deposits on Mars. Icarus, 292, 125-143. https://doi.org/ 10.1016/j.icarus.2016.12.023

Anderson, J. A., Sides, S. C., Soltesz, D. L., Sucharski, T. L., \& Becker, K. J. (2004). Modernization of the integrated software for imagers and spectrometers, in 35th Lunar and Planetary Science Conference, Abstract \#2039.

Andrews-Hanna, J. C., \& Lewis, K. W. (2011). Early Mars hydrology: 2. Hydrological evolution in the Noachian and Hesperian epochs. Journal of Geophysical Research, 116, E02007. https://doi.org/10.1029/2010JE003709

Andrews-Hanna, J. C., Phillips, R. J., \& Zuber, M. T. (2007). Meridiani Planum and the global hydrology of Mars. Nature, 446(7132), 163-166. https://doi.org/10.1038/nature05594

Andrews-Hanna, J. C., Zuber, M. T., Arvidson, R. E., \& Wiseman, S. M. (2010). Early Mars hydrology: Meridiani playa deposits and the sedimentary record of Arabia Terra. Journal of Geophysical Research, 115, 5138. https://doi.org/10.1029/2009JE003485

Ansan, V., Loizeau, D., Mangold, N., Le Mouélic, S., Carter, J., Poulet, F., et al. (2011). Stratigraphy, mineralogy, and origin of layered deposits inside Terby crater, Mars. Icarus, 211, 273-304. https://doi.org/10.1016/j.icarus.2010.09.011

Baioni, D., \& Sgavetti, M. (2013). Karst terrains as possible lithologic and stratigraphic markers in northern Sinus Meridiani, Mars. Planetary and Space Science, 75, 173-181. https://doi.org/10.1016/j.pss.2012.08.011

Baioni, D., \& Tramontana, M. (2017). Possible evaporite karst in an interior layered deposit in Juventae Chasma, Mars. International Journal of Speleology, 46, 181-189. https://doi.org/10.5038/1827-806X.46.2.2085

Bargar, E. (1978). Geology and thermal history of Mammoth Hot Springs, Yellowstone National Park, Wyoming, Report, U.S.G.S. Numbered Series, 1444.

Bennett, K., \& Bell, J. (2016). A global survey of Martian central mounds: Central mounds as remnants of previously more extensive largescale sedimentary deposits. Icarus, 264, 331-341. https://doi.org/10.1016/j.icarus.2015.09.041

Bibring, J.-P., Langevin, Y., Gendrin, A., Gondet, B., Poulet, F., Berthé, M., et al. (2005). Mars surface diversity as revealed by the OMEGA/Mars Express observations. Science, 307, 1576-1581. https://doi.org/10.1126/science.1108806 
Bibring, J. P., Langevin, Y., Mustard, J. F., Poulet, F., Arvidson, R., Gendrin, A., et al. (2006). Global mineralogical and aqueous Mars history derived from OMEGA/Mars express data. Science, 312, 400-404. https://doi.org/10.1126/science.1122659

Bishop, J. L., Noe Dobrea, E. Z., McKeown, N. K., Parente, M., Ehlmann, B. L., Michalski, J. R., et al. (2008). Phyllosilicate diversity and past aqueous activity revealed at Mawrth Vallis, Mars. Science, 321, 830-833. https://doi.org/10.1126/science.1159699

Bridges, N., \& Ehlmann, B. (2018). The Mars Science Laboratory (MSL) Bagnold Dunes Campaign, Phase I: Overview and introduction to the special issue. Journal of Geophysical Research: Planets, 123, 3-19. https://doi.org/10.1002/2017JE005401

Brogi, A., \& Capezzuoli, E. (2009). Travertine deposition and faulting: The fault-related travertine fissure-ridge at Terme S. Giovanni, Rapolano Terme (Italy). International Journal of Earth Sciences, 98, 931-947. https://doi.org/10.1007/s00531-007-0290-z

Broxton, M. J., \& Edwards, L. J. (2008). The Ames Stereo Pipeline: Automated 3D surface reconstruction from Orbital Imagery, in 39th Lunar and Planetary Science Conference, p. Abstract \#2419.

Bruno, D. E., \& Ruban, D. A. (2016). Something more than boulders-A geological comment on the nomenclature of megaclasts on extraterrestrial bodies. Planetary and Space Science, 135, 37-42. https://doi.org/10.1016/j.pss.2016.11.006

Bruthans, J., Filippi, M., Asadi, N., Zare, M., Šlechta, S., \& Churáčková, Z. (2009). Surficial deposits on salt diapirs (Zagros Mountains and Persian Gulf Platform, Iran): Characterization, evolution, erosion and the influence on landscape morphology. Geomorphology, 107, 195-209. https://doi.org/10.1016/j.geomorph.2008.12.006

Cadieux, S., \& Kah, L. (2015). To what extent can intracrater layered deposits that lack clear sedimentary textures be used to infer depositional environments? Icarus, 248, 526-538. https://doi.org/10.1016/j.icarus.2014.11.004

Capezzuoli, E., Ruggieri, G., Rimondi, V., Brogi, A., Liotta, D., Alçiçek, M. C., et al. (2018). Calcite veining and feeding conduits in a hydrothermal system: Insights from a natural section across the Pleistocene Gölemezli travertine depositional system (western Anatolia, Turkey). Sedimentary Geology, 364, 180-203. https://doi.org/10.1016/j.sedgeo.2017.12.012

Chan, M., Yonkee, A., Netoff, D., Seiler, W., \& Ford, R. (2008). Polygonal cracks in bedrock on Earth and Mars: Implications for weathering. Icarus, 194, 65-71. https://doi.org/10.1016/j.icarus.2007.09.026

Chan, M. A., \& Netoff, D. I. (2017). A terrestrial weathering and wind abrasion analog for mound and moat morphology of Gale crater, Mars. Geophysical Research Letters, 44, 4000-4007. https://doi.org/10.1002/2017GL072978

Chapman, M. G., \& Tanaka, K. L. (2001). Interior trough deposits on Mars: Subice volcanoes? Journal of Geophysical Research, 106(E5), 10,087-10,100. https://doi.org/10.1029/2000JE001303

Chapman, M. G., \& Tanaka, K. L. (2002). Related magma-ice interactions: Possible origins of chasmata, chaos, and surface materials in Xanthe, Margaritifer, Meridiani Terrae, Mars. Icarus, 155(2), 324-339. https://doi.org/10.1006/icar.2001.6735

Chavdarian, G. V., \& Sumner, D. Y. (2006). Cracks and fins in sulfate sand: Evidence for recent mineral-atmospheric water cycling in Meridiani Planum outcrops? Geology, 34, 229-232. https://doi.org/10.1130/G22101.1

Clifford, S., Lasue, J., Heggy, E., Boisson, J., McGovern, P., \& Max, M. (2010). Depth of the Martian cryosphere: Revised estimates and implications for the existence and detection of subpermafrost groundwater. Journal of Geophysical Research, Planets, 115(E7). https://doi.org/10.1029/2009JE003462

Davis, J., Grindrod, P., Fawdon, P., Williams, R., Gupta, S., \& Balme, M. (2018). Episodic and declining fluvial processes in southwest Melas Chasma, Valles Marineris, Mars. Journal of Geophysical Research: Planets, 123, 2527-2549. https://doi.org/10.1029/2018JE005710

Day, M., Anderson, W., Kocurek, G., \& Mohrig, D. (2016). Carving intracrater layered deposits with wind on Mars. Geophysical Research Letters, 43, 2473-2479. https://doi.org/10.1002/2016GL068011

Edgett, K. S., \& Malin, M. C. (2000). Martian sedimentary rock stratigraphy: Outcrops and interbedded craters of northwest Sinus Meridiani and Southwest Arabia Terra. Geophysical Research Letters, 29(24), 32-31.

El-Maarry, M. R., Pommerol, A., \& Thomas, N. (2013). Analysis of polygonal cracking patterns in chloride-bearing terrains on Mars: Indicators of ancient playa settings. Journal of Geophysical Research, E: Planets, 118, 2263-2278. https://doi.org/10.1002/ 2013JE004463

Flahaut, J., Quantin, C., Allemand, P., \& Thomas, P. (2010). Morphology and geology of the ILD in Capri/Eos Chasma (Mars) from visible and infrared data. Icarus, 207, 175-185. https://doi.org/10.1016/j.icarus.2009.11.019

Flahaut, J., Quantin, C., Allemand, P., Thomas, P., \& Le Deit, L. (2010). Identification, distribution and possible origins of sulfates in Capri Chasma (Mars), inferred from CRISM data. Journal of Geophysical Research, 115, E02003. https://doi.org/10.1029/2009JE003566

Franchi, F., Rossi, A. P., Pondrelli, M., \& Cavalazzi, B. (2014). Geometry, stratigraphy and evidences for fluid expulsion within Crommelin crater deposits, Arabia Terra, Mars. Planetary and Space Science, 92, 34-48. https://doi.org/10.1016/j.pss.2013.12.013

Fryberger, S. G., Schenk, C. J., \& Krystinik, L. F. (1988). Stokes surfaces and the effects of near-surface groundwater-table on Aeolian deposition. Sedimentology, 35(1), 21-41. https://doi.org/10.1111/j.1365-3091.1988.tb00903.x

Fueten, F., Flahaut, J., Stesky, R., Hauber, E., \& Rossi, A. (2014). Stratigraphy and mineralogy of Candor Mensa, West Candor Chasma, Mars: Insights into the geologic history of Valles Marineris. Journal of Geophysical Research: Planets, 119, 331-354. https://doi.org/ 10.1002/2013JE004557

Fueten, F., Novakovic, N., Stesky, R., Flahaut, J., Hauber, E., \& Rossi, A. P. (2017). The evolution of Juventae Chasma, Valles Marineris, Mars: Progressive collapse and sedimentation. Journal of Geophysical Research: Planets, 122, 2223-2249. https://doi.org/10.1002/ 2017JE005334

Fueten, F., Stesky, R., MacKinnon, P., Hauber, E., Zegers, T., Gwinner, K., et al. (2008). Stratigraphy and structure of interior layered deposits in west Candor Chasma, Mars, from High Resolution Stereo Camera (HRSC) stereo imagery and derived elevations. Journal of Geophysical Research, 113, E11004. https://doi.org/10.1029/2007JE003053

Garvin, J. B., Sakimoto, S., \& Frawley, J. J. (2003). Craters on Mars: Global geometric properties from gridded MOLA topography, Sixth International Conference on Mars (2003), Abstract 3277.

Gendrin, A., Mangold, N., Bibring, J. P., Langevin, Y., Gondet, B., Poulet, F., et al. (2005). Sulfates in Martian layered terrains: The OMEGA/Mars Express view. Science, 307, 1587-1591. https://doi.org/10.1126/science.1109087

Glotch, T., \& Rogers, A. (2007). Evidence for aqueous deposition of hematite- and sulfate-rich light-toned layered deposits in Aureum and Iani Chaos, Mars. Journal of Geophysical Research, 112, E06001. https://doi.org/10.1029/2006JE002863

Goodall, T., North, C., \& Glennie, K. (2000). Surface and subsurface sedimentary structures produced by salt crusts. Sedimentology, 47(1), 99-118. https://doi.org/10.1046/j.1365-3091.2000.00279.x

Grotzinger, J. P., Arvidson, R. E., Calvin, B. J. W. III, Clark, B. C., Fike, D. A., Golombek, M., et al. (2005). Stratigraphy and sedimentology of a dry to wet eolian depositional system, Burns formation, Meridiani Planum, Mars. Earth and Planetary Science Letters, $240,11-72$. https://doi.org/10.1016/j.epsl.2005.09.039

Handford, C. R. (1982). Sedimentology and evaporite genesis in a Holocene continental-sabkha playa basin-Bristol Dry Lake, California. Sedimentology, 29(2), 239-253. https://doi.org/10.1111/j.1365-3091.1982.tb01721.x 
Hurst, A., Scott, A., \& Vigorito, M. (2011). Physical characteristics of sand injectites. Earth Science Reviews, 106, 215-246. https://doi.org/ 10.1016/j.earscirev.2011.02.004

Hynek, B. M., Arvidson, R. E., \& Phillips, R. J. (2002). Geologic setting and origin of Terra Meridiani hematite deposit on Mars. Journal of Geophysical Research, 107(E10), 5088. https://doi.org/10.1029/2002JE001891

Hynek, B. M., \& Di Achille, G. (2017). Geologic map of Meridiani Planum, Mars, US Geological Survey Scientific Investigations Map, 3356.

Hynek, B. M., Phillips, R. J., \& Arvidson, R. E. (2003). Explosive volcanism in the Tharsis region: Global evidence in the Martian geologic record, Journal of Geophysical Research, 108(9), 5111, 15-11.https://doi.org/10.1029/2003JE002062

Jaumann, R., Tirsch, D., Hauber, E., Ansan, V., di Achille, G., Erkeling, G., et al. (2015). Quantifying geological processes on Mars-Results of the high resolution stereo camera (HRSC) on Mars express. Planetary and Space Science, 112, 53-97. https://doi.org/10.1016/j. pss.2014.11.029

Kerber, L., Head, J. W., Madeleine, J.-B., Forget, F., \& Wilson, L. (2012). The dispersal of pyroclasts from ancient explosive volcanoes on Mars: Implications for the friable layered deposits. Icarus, 219, 358-381. https://doi.org/10.1016/j.icarus.2012.03.016

Kite, E. S., Lewis, K. W., Lamb, M. P., Newman, C. E., \& Richardson, M. I. (2013). Growth and form of the mound in Gale Crater, Mars: Slope wind enhanced erosion and transport. Geology, 41, 543-546. https://doi.org/10.1130/G33909.1

Knauth, P. L., Burt, D. M., \& Wohletz, K. H. (2005). Impact origin of sediments at the Opportunity landing site on Mars. Nature, 438, 1123-1128. https://doi.org/10.1038/nature04383

Komatsu, G., Ori, G., Ciarcelluti, P., \& Litasov, Y. D. (2004). Interior layered deposits of Valles Marineris, Mars: Analogous subice volcanism related to Baikal Rifting, Southern Siberia. Planetary and Space Science, 52, 167-187. https://doi.org/10.1016/j.pss.2003.08.003

Le Deit, L., Flahaut, J., Quantin, C., Hauber, E., Mège, D., Bourgeois, O., et al. (2012). Extensive surface pedogenic alteration of the Martian Noachian crust suggested by plateau phyllosilicates around Valles Marineris. Journal of Geophysical Research, 117, E00J05. https://doi. org/10.1029/2011JE003983

Le Deit, L., Hauber, E., Fueten, F., Pondrelli, M., Rossi, A., \& Jaumann, R. (2013). Sequence of infilling events in Gale crater, Mars: Results from morphology, stratigraphy, and mineralogy. Journal of Geophysical Research: Planets, 118, 2439-2473. https://doi.org/10.1002/ 2012JE004322

Le Deit, L., Mouélic, S., Bourgeois, O., Combe, J., Mège, D., Sotin, C., et al. (2008). Ferric oxides in East Candor Chasma, Valles Marineris (Mars) inferred from analysis of OMEGA/Mars Express data: Identification and geological interpretation. Journal of Geophysical Research, 113, E12004. https://doi.org/10.1029/2007JE002950

Lewis, K. W., Aharonson, O., Grotzinger, J. P., Kirk, R. L., McEwen, A. S., \& Suer, T. A. (2008). Quasi-periodic bedding in the sedimentary rock record of mars. Science, 322, 1532-1535. https://doi.org/10.1126/science.1161870

Lucchitta, B. K., McEwen, A. S., Clow, G. D., Geissler, P. E., Singer, R. B., Schultz, R. A., \& Squyres, S. W. (1992). The canyon system on Mars. Mars, 453-492.

Madden, M. E. E., Bodnar, R. J., \& Rimstidt, J. D. (2004). Jarosite as an indicator of water-limited chemical weathering on Mars. Nature, 431(7010), 821-823. https://doi.org/10.1038/nature02971

Malin, M. C., Bell, J. F., Cantor, B. A., Caplinger, M. A., Calvin, W. M., Clancy, T. R., et al. (2007). Context camera investigation on board the Mars Reconnaissance Orbiter. Journal of Geophysical Research, 112, E05S04. https://doi.org/10.1029/2006JE002808

Malin, M. C., \& Edgett, K. S. (2000). Sedimentary rocks of early Mars. Science, 290(5498), 1927-1937. https://doi.org/10.1126/ science.290.5498.1927

Mangold, N., Gendrin, A., Gondet, B., LeMouelic, S., Quantin, C., Ansan, V., et al. (2008). Spectral and geological study of the sulfate-rich region of West Candor Chasma, Mars. Icarus, 194(2), 519-543. https://doi.org/10.1016/j.icarus.2007.10.021

McEwen, A. S., Eliason, E. M., Bergstrom, J. W., Bridges, N. T., Hansen, C. J., Delamere, A. W., et al. (2007). Mars Reconnaissance Orbiter's High Resolution Imaging Science Experiment (HiRISE). Journal of Geophysical Research, 112, E05S02. https://doi.org/10.1029/ 2005JE002605

McLennan, S. M., Bell, J., Calvin, W. M., Christensen, P., Clark, B. C., de Souza, P. A., et al. (2005). Provenance and diagenesis of the evaporite-bearing Burns formation, Meridiani Planum, Mars. Earth and Planetary Science Letters, 240, 95-121. https://doi.org/10.1016/j. epsl.2005.09.041

Michalski, J., \& Niles, P. B. (2012). Atmospheric origin of Martian interior layered deposits: Links to climate change and the global sulfur cycle. Geology, 40, 419-422. https://doi.org/10.1130/g32971.1

Michalski, J. R., Cuadros, J., Niles, P. B., Parnell, J., Rogers, D. A., \& Wright, S. P. (2013). Groundwater activity on Mars and implications for a deep biosphere. Nature Geoscience, 6(2), 133-138. https://doi.org/10.1038/ngeo1706

Moore, J. M., \& Wilhelms, D. E. (2007). Geologic map of part of western Hellas Planitia, Mars. U. S Geological Survey Miscellaneous Investigation Series, I-2953.

Moratto, Z. M., Broxton, M. J., Beyer, R. A., Lundy, M., \& Husmann, K. (2010). Ames Stereo Pipeline, NASA's Open Source Automated Stereogrammetry Software, in 41st Lunar and Planetary Science Conference, p. Abstract \#2364.

Morgan, F., Seelos, F. P., Murchie, S. L., \& the CRISM Team (2014). In R. G. Gaddis, T. Hare, \& R. Beyer (Eds.), CRISM Analysis Toolkit (CAT)Open-File Report 2014-1056 (pp. 125-126). Reston, VA, USA: U.S. Geological Survey.

Murana, A. (2018). Geology of Danielson Crater, Mars. Journal of Maps, 14, 161-172. https://doi.org/10.1080/17445647.2018.1443029

Murchie, S., Arvidson, R., Bedini, P., Beisser, K., Bibring, J., Bishop, J., et al. (2007). Compact Reconnaissance Imaging Spectrometer for Mars (CRISM) on Mars Reconnaissance Orbiter (MRO). Journal of Geophysical Research, 112, EO5S03. https://doi.org/10.1029/ 2006JE002682

Murchie, S., Roach, L., Seelos, F., Milliken, R., Mustard, J., Arvidson, R., et al. (2009). Evidence for the origin of layered deposits in Candor Chasma, Mars, from mineral composition and hydrologic modeling. Journal of Geophysical Research, 114, E00D05. https://doi.org/ 10.1029/2009JE003343

Neukum, G., Jaumann, R., Hoffmann, H., and the Mars Express HRSC Team (2004). HRSC-The High Resolution Stereo Camera of Mars Express, European Space Agency Special Publication, SP-1240, 17-35.

Newsom, H. E., Barber, C. A., Hare, T. M., Schelble, R. T., Sutherland, V. A., \& Feldman, W. C. (2003). Peleolakes and impact basins in southern Arabia Terra, including Meridiani Planum: Implications for the formation of hematite deposits on Mars. Journal of Geophysical Research, 108(E12), 8075. https://doi.org/10.1029/2002JE001993

Noel, A., Bishop, J., Al-Samir, M., Gross, C., Flahaut, J., McGuire, P., et al. (2015). Mineralogy, morphology and stratigraphy of the lighttoned interior layered deposits at Juventae Chasma. Icarus, 251, 315-331. https://doi.org/10.1016/j.icarus.2014.09.033

Oehler, D. Z., \& Allen, C. C. (2010). Evidence for pervasive mud volcanism in Acidalia Planitia, Mars. Icarus, 208, 636-657. https://doi.org/ 10.1016/j.icarus.2010.03.031 
Okubo, C. H., Schultz, R. A., Chan, M. A., \& Komatsu, G. (2009). Deformation band clusters on Mars and implications for subsurface fluid flow. Geological Society of America Bulletin, 121, 474-482. https://doi.org/10.1130/B26421.1

Pangaea Scientific (2006-2011). Orion: Orientation hunter [computer software]. Supported by Canada Centre for Remote Sensing. Brockville, Ontario, Canada: Natural Resources Canada.

Pelletier, J., Kapp, P., Abell, J., Field, J., Williams, Z., \& Dorsey, R. (2018). Controls on yardang development and morphology: 1. Field observations and measurements at Ocotillo Wells, California. Journal of Geophysical Research: Earth Surface, 123(4), 694-722. https:// doi.org/10.1002/2017JF004461

Pondrelli, M., Baker, V. R., \& Hauber, E. (2018). Geologic tools. In A. P. Rossi, \& S. van Gasselt (Eds.), Planetary geologySpringer Praxis Books (pp. 15-32). Cham: Springer. https://doi.org/10.1007/978-3-319-65179-8_2

Pondrelli, M., Rossi, A. P., Deit, L. L., van Gasselt, S., Fueten, F., Glamoclija, M., et al. (2015). Equatorial layered deposits in the Firsoff crater area: Process variability and habitability potential. Geological Society of America Bulletin, 127, 1064-1089. https://doi.org/10.1130/ B31225.1

Pondrelli, M., Rossi, A. P., Ori, G. G., van Gasselt, S., Praeg, D., \& Ceramicola, S. (2011). Mud volcanoes in the geologic record of Mars: The case of Firsoff crater. Earth and Planetary Science Letters, 304, 511-519. https://doi.org/10.1016/j.epsl.2011.02.027

Poulet, F., Arvidson, R. E., Gomez, C., Morris, R. V., Bibring, J. P., Langevin, Y., et al. (2008). Mineralogy of Terra Meridiani and western Arabia Terra from OMEGA/MEx and implications for their formation. Icarus, 195, 106-130. https://doi.org/10.1016/j.icarus.2007.11.031

Pozzobon, R., Mazzarini, F., Massironi, M., Rossi, A. P., Pondrelli, M., Cremonese, G., \& Marinangeli, L. (2019). Fluids mobilization in Arabia Terra, Mars: Depth of pressurized reservoir from mounds self-similar clustering. Icarus, 321, 938-959. https://doi.org/10.1016/j. icarus.2018.12.023

Quantin, C., Allemand, P., Mangold, N., Dromart, G., \& Delacourt, C. (2005). Fluvial and lacustrine activity on layered deposits in Melas Chasma, Valles Marineris, Mars. Journal of Geophysical Research, 110, E12S19. https://doi.org/10.1029/2005JE002440

Reading, H. G. (2009). Sedimentary environments: Processes, facies and stratigraphy (3rd ed.). Oxford: Blackwell Science Ltd.

Robbins, S., \& Hynek, B. (2013). Utility of laser altimeter and stereoscopic terrain models: Application to Martian craters. Planetary and Space Science, 86, 57-65. https://doi.org/10.1016/j.pss.2013.06.019

Rossi, A. P., Neukum, G., Pondrelli, M., van Gasselt, S., Zegers, T., Hauber, E., et al. (2008). Large-scale spring deposits on Mars? Journal of Geophysical Research, 113, E04016. https://doi.org/10.1029/2007JE003062

Salese, F., Ansan, V., Mangold, N., Carter, J., Ody, A., Poulet, F., \& Ori, G. (2016). A sedimentary origin for intercrater plains north of the Hellas basin: Implications for climate conditions and erosion rates on early Mars. Journal of Geophysical Research: Planets, 121, 2239-2267. https://doi.org/10.1002/2016JE005039

Salese, F., Pondrelli, M., Neeseman, A., Schmidt, G., \& Ori, G. G. (2019). Geological evidence of planet-wide groundwater system on Mars. Journal of Geophysical Research: Planets, 124. https://doi.org/10.1029/2018JE005802

Schmidt, G., Fueten, F., Stesky, R., Flahaut, J., \& Hauber, E. (2018). Geology of Hebes Chasma, Mars: 1. Structure, stratigraphy, and mineralogy of the interior layered deposits. Journal of Geophysical Research: Planets, 123, 2893-2919. https://doi.org/10.1029/ 2018JE005658

Schmidt, G., Pondrelli, M., Salese, F., \& Rossi, A. (2018). Distribution, stratigraphy, and layer thicknesses of intra-crater deposits in Western Arabia Terra, Mars. Lunar Planet. Sci., XLIX, Abstract 1916

Scott, D. H., \& Tanaka, K. L. (1982). Ignimbrites of Amazonis Planitia region of Mars. Journal of Geophysical Research, 87(B2), 1179-1190. https://doi.org/10.1029/JB087iB02p01179

Scott, D. H., \& Tanaka, K. L. (1986). Geologic map of the western equatorial region of Mars, US Geol. Surv. Misc. Invest. Ser., Map I-1802-A.

Smith, D. E., Zuber, M. T., Frey, H. V., Garvin, J. B., Head, J. W., Muhleman, D. O., et al. (2001). Mars Orbiter Laser Altimeter: Experiment summary after the first year of global mapping of Mars. Journal of Geophysical Research, 106(E10), 23,689-23,722. https://doi.org/ 10.1029/2000JE001364

Taj, R., \& Aref, M. (2015). Structural and textural characteristics of surface halite crusts of a supratidal, ephemeral halite pan, South Jeddah, Red Sea Coast, Saudi Arabia. Facies, 61, 1-15. https://doi.org/10.1007/s10347-014-0426-0

Tanaka, K., Skinner J., Dohm J., Irwin R., Kolb E., Fortezzo C., et al. (2014), Geologic map of Mars, USGS Scientific Investigations Map 3292, https://doi.org/10.3133/sim3292

Tanaka, K. L. (2000). Dust and ice deposition in the Martian geologic record. Icarus, 144(2), 254-266. https://doi.org/10.1006/ icar.1999.6297

Van Rensbergen, P., Hillis, R. R., Maltman, A. J., \& Morley, C. K. (2003). Subsurface sediment mobilization: Introduction. Geological Society Special Publication, 216(1), 1-8. https://doi.org/10.1144/GSL.SP.2003.216.01.01

Várkonyi, P., Laity, J., \& Domokos, G. (2016). Quantitative modeling of facet development in ventifacts by sand abrasion. Aeolian Research, 20, 25-33. https://doi.org/10.1016/j.aeolia.2015.10.006

Viviano-Beck, C. E., Seelos, F. P., Murchie, S. L., Kahn, E. G., Seelos, K. D., Taylor, H. W., et al. (2014). Revised CRISM spectral parameters and summary products based on the currently detected mineral diversity on Mars. Journal of Geophysical Research: Planets, 119, 1403-1431. https://doi.org/10.1002/2014JE004627

Weiss, D., \& Head, J. (2017). Evidence for stabilization of the ice-cemented cryosphere in earlier Martian history: Implications for the current abundance of groundwater at depth on Mars. Icarus, 288, 120-147. https://doi.org/10.1016/j.icarus.2017.01.018

Weitz, C., Dobrea, E., Lane, M., \& Knudson, A. (2012). Geologic relationships between gray hematite, sulfates, and clays in Capri Chasma. Journal of Geophysical Research, 117, E00J09. https://doi.org/10.1029/2012JE004092

Weitz, C., Milliken, R., Grant, J., McEwen, A., Williams, R., \& Bishop, J. (2008). Light-toned strata and inverted channels adjacent to Juventae and Ganges chasmata, Mars. Geophysical Research Letters, 35, L19202. https://doi.org/10.1029/2008GL035317

Wilson, S. A., Howard, A. D., Moore, J. M., \& Grant, J. A. (2007). Geomorphic and stratigraphic analysis of Crater Terby and layered deposits north of Hellas basin, Mars. Journal of Geophysical Research, 112, E08009. https://doi.org/10.1029/2006JE002830

Zabrusky, K., Andrews-Hanna, J. C., \& Wiseman, S. M. (2012). Reconstructing the distribution and depositional history of the sedimentary deposits of Arabia Terra, Mars. Icarus, 220, 311-330. https://doi.org/10.1016/j.icarus.2012.05.007 